\title{
Beyond the Rhetoric of Assimilation and Cultural Pluralism: Addressing the Tension of Separatism and Conflict in an Immigration- Driven Multiracial Society
}

\author{
Bill Ong Hing $\dagger$
}

Immigration is quickly changing the racial demographics of the United States. In so doing, it is creating both tensions and opportunities. The author responds to those who advocate restricted immigration as the solution to racial problems. He refutes the underlying assumptions of such Euro-immigrationists: that the United States has a solely white, Christian, and European heritage, and that other immigrants have failed to acculturate. Furthermore, cultural pluralism in a multiracial society has several benefits, including its connection to constitutional principles and its advantages in both the global and the increasingly diverse domestic economy. In turn, the author takes cultural pluralists to task for not grappling sufficiently with interethnic confict and separatism. While interethnic conflict and separatist sentiment are exacerbated by society's exclusion of people of color, they are problems that cannot be ignored. The author articulates a new approach to cultural pluralism in a broader definition of America. This new approach would respect diverse views and cultures, including the right of separatists within communities of color. It would also require adherence to a common core of values, including respect for the laws, for the democratic political and economic system, and for equal opportunity.

\section{INTRODUCTION}

I think God made all people good, but if we had to take a million immigrants in, say, Zulus, next year or Englishmen and

$\dagger$ Associate Professor of Law, Stanford Law School. I have many people to thank for this article. Many friends provided helpful comments on earlier drafts: Paul Brest, Lawrence Friedman, Gerry Gunther, Mark Kelman, Bill McGowan, Joyce Hing McGowan, Mark Silverman, Bill Simon, Michael Wald, and especially Tom Grey. I also benefited from conversations on Americanization, separatism, and ethnic conflict with Cecelia Burciaga, Dawn Chirwa, Lenora Fung, Char Hamada, Jayne Lee, Shauna Marshall, Miguel Méndez, Yvonne Yazzie Nakahigashi, and Cruz Reynoso. Stephen Carpenter and Emily Dentzer provided excellent research assistance. Finally, Daina Chiu and the other staff members of the California Law Review deserve special thanks for their advice and hard work on the piece. 
put them in Virginia, what group would be easier to assimilate and would cause less problems for the people of Virginia? There is nothing wrong with us sitting down and arguing that issue, that we are a European country....

…

... [E]very immigration policy is going to let somebody in and keep somebody out. It's going to have different criteria. What I am saying is culture, language, background are not illegitimate criteria for us to discuss when we discuss legal immigration.

-Patrick Buchanan ${ }^{1}$

America is a pohtical union-not a cultural, linguistic, religious or racial union. . . Of course, we as individuals would urge all to learn. English for that is the language used by most Americans as well as the language of the marketplace. But, we should no more demand English-language skills for citizenship than we should demand uniformity of religion. That a person wants to become a citizen and will make a good citizen is more than enough.

- Honorable Cruz Reynoso ${ }^{2}$

Whenever the immigrant group refuses to adapt to the dominant culture, conficts can emerge. This is especially true when the number of such immigrants is relatively large and comes from $a$ single source. Whenever the host group refuses to allow the newcomers to participate in the activities of the society, cultural conflicts can emerge.

-Leon Bouvier ${ }^{3}$

To separate [children in grade and high schools] from others of similar age and qualiflcations solely because of their race gener. ates a feeling of inferiority as to their status in the community that may affect their hearts and minds in a way unlikely ever to be undone.

-Chief Justice Earl Warren, Brown v. Board of Education ${ }^{4}$

I think the integration of black folks in the 60's was one of the biggest cons in the world... I I was called a nigger the flrst week [at the University of Connecticut in 1970] and held by the police until this white girl told them I hadn't attacked her. You want to call me a separatist, so be it. I think of myself as a pragmatist. Why should I beg some cracker to integrate me into his society

1. This Week With David Brinkley, (ABC News television broadcast, Dec. 8, 1991).

2. Select COMm'N ON IMmigration \& Refugee Policy, U.S. ImMigration Policy AND THE NATIONAL INTEREST 403-04 (1981) (statement of Commissioner Cruz Reynoso, Associate Justice, California Court of Appeals).

3. Leon F. Bouvier, Peaceful Invasions: Immigration and Changing America 18485 (1992).

4. 347 U.S. 483,494 (1954). 
when he doesn't want to? Why keep beating my head up against a wall, especially when I've been there[?]

....

... What I reject is this notion that we are aiming toward an integrated county .... African Americans should be aiming toward an ability to control our own destiny.

\section{-Radamase Cabrera ${ }^{5}$ \\ Many [immigrants living in Little India are] not doing their part of integrating.}

-Dhanesh Bhindi ${ }^{6}$

Demographic changes in the country over the past two decades have refueled a debate between assimilatiomsts and cultural pluralists that seemed to have subsided when Congress eliminated national origins quota restrictions froin our immigration laws in $1965 .^{7}$ Between 1970 and 1990 , the population of the Umited States mcreased by $22.4 \% .^{8}$ The African American population increased by $33 \%$ to reach $12.1 \%$ of the total population. ${ }^{9}$ The Latino and Asian American growth was particularly phenomenal. The Latino population mcreased by $141 \%$ to reach $9 \%$ of the total population. ${ }^{10}$ The Asian American population grew by a striking $384.9 \%$ to reach $2.9 \%$ of the total population. ${ }^{11}$ The Native American population, which was $0.4 \%$ of the 1970 population, is now $0.8 \%$ of the population. ${ }^{12}$ Immigration has accounted for inuch of the

5. David J. Dent, The New Black Suburbs, N.Y. Times, June 14, 1992, § 6 (Magazine), at 18, 20-21 (quoting Radamase Cabrera). Bhindi).

6. Scott Harris, 'Little India,' L.A. Times, Sept. 1, 1992, at B1, B3 (quoting Dhanesh

7. See infra notes 201-05 and accompanying text.

8. The U.S. population increased from $203,210,158$ in 1970 to $248,709,873$ in 1990 . See Bureau of the Census, U.S. DeP'T of COMMerce, 1970 Census of Population: Detailed Characteristics-UNITEd States SumMary 591 tbl. 189 (1973) [hereinafter 1970 Census]; Bureau of the Census, U.S. Dep't of Commerce, 1990 Census of Population and Housing: Summary Population and Housing Characteristics-United STates 59 tbl. 2 (1992) [hereinafter 1990 CENSUS].

9. The African American population increased from 22,539,362 to $29,986,060$. See 1970 CENSUS, supra note 8, at 593 tbl. 190; 1990 CENSUS, supra note 8, at 59 tbl. 2.

10. The Latino population increased from $9,294,509$ to $22,354,059$. See 1970 Census, supra note 8, at 595 tbl. 190; 1990 Census, supra note 8, at 59 tbl. 2.

11. See 1970 Census, supra note 8, at 593-94 tbl. 190. The Asian American population increased from about 1,500,065 to 7,273,662 between 1970 and 1990. The Asian American population for 1970 is an approximation based on the following figures available for the 1970 census: 586,675 Japanese; 433,469 Chinese; 336,823 Filipinos; and 70,598 Koreans. Added to these figures is 72,500 representing an estimate of the number of Asian Indians in the United States in 1970. See Bill Ong Hing, Making and Remaking asian America Through Immigration Policy 1850-1990, at 70 tbl. 8 (1993). By 1990, the figures were as follows: $1,645,472$ Chinese; $1,406,770$ Filipinos; 847,562 Japanese; 815,447 Asian Indians; 798,849 Korcans; and 614,547 Vietnamese. See HING, supra at 4 tbl. 2.

12. The Native American population in 1970 was 760,572 . See 1970 CENSUs, supra note 8 , at 593 tbl. 190. The 1990 Census counted 1,959,234 Native Americans. 1990 Census, supra note 8 , at $59 \mathrm{tbl}$. 2. The 1990 figures cited here include Eskimo and Aleut, whereas the 1970 figures do not. 
growth in the Latino and Asian American communities. Froin 1971 to 1990, nearly nine million immigrants entered from Asian and Latin American countries. ${ }^{13}$ During the 1990 s, inore than half a million immigrants are expected to enter each year; Asian and Latino mımigrants will make up $75 \%$ of that nuniber. ${ }^{14}$

These enormous changes in the demographic composition of America have focused debate on what it ineans to become an American. Pundits, commentators, scholars, and politicians have weighed in on all sides, and their conclusions have significant influence on our nation's mimigration policies. The discussion, however, implicates society far beyond the realm of proposed federal immigration policy. The discussion of who is and who is not American, who can and caimot become American, goes beyond the technicalities of citizenship and residency requireinents; it strikes at the very heart of our nation's long and troubled legacy of race relations. Underlying the debate over immigrants and American identity is a concern about the interaction, or lack of interaction, anong different racial groups.

My own experiences from childhood through adolescence, young adulthood, and beyond have shaped my views of race, assimilation, and our inultiracial society. I grew up in Superior, Arizona, a copper mining town of about 5000 people in the east-central part of the state. I was the youngest of ten children in one of three Chinese Annerican families (or one extended family, smce their inembers were iny uncles, aunts, and cousins) in Superior. I spoke inainly Cantonese to my immigrant parents, ${ }^{15}$ and Enghish to iny American-born siblings. We had a small grocery adjacent to our house, and since Superior was predominantly Mexican American, I spoke Spanish to our older customers and a combination of Spamish and Enghish to the other children in the neighborhood and at school. Speaking Spanish on school grounds was prohibited. Soine of our customers and my classmates were Native American, mostly Navajo. With them I spoke Enghish.

I learned a lot about Mexican American culture growing up in Superior. I spent a good deal of time at my friend Leonard Martinez's house, eating and talking with Leonard and his grandmother, who was

13. In these years 4,326,335 immigrants entered from Asia and 4,466,064 from Latin America. These figures are calculated from the 1990 Statistical Yearbook of the Immigration and Naturalization Service. 1990 INS STAT. Y.B. 50 tbl. 2.

14. These estimates are my own, projected from immigration statistics of the 1980s. They reflect the fact that figures for Latin American immigratiou in that decade were higher than normal due to legalization. See id. at 30.

15. My mother was actually born in Scranton, Pennsylvania in 1901, but accompanied her mother to China at the age of three to care for an ailing grandmother. My mother did not return to the Uuited States until 1925, as the spouse of my father who was born in Canton, China, but who claimed to be the son of a U.S. citizen. Many Chinese immigrants entered the United States as "paper sons" in response to exclusionary immigration laws. See HiNG, supra note 11, at 74; RoNald TAKaki, Strangers From A Different Shore 110-12, 234-37 (1989). 
from Mexico. I learned about hunting from his grandfather and uncles by listening to their stories and sharing in the celebration when they returned from trips with deer, rabbit, wild boar, or quail. The father of iny friend Ray Ramirez taught me how to sing and play several Mexican corridos on the guitar. My friend Diana Viramontes was great at sandlot baseball and at cracking open piñatas blindfolded at birthday parties. She once even introduced me to her Girl Scout friend Mary Rose Garrido, whom I had a crush on for several years afterwards. It was not uncommon for some Mexican children to taunt me verbally because I was Chinese. But I was good at defending myself, and it was not unusual for my Mexican friends to join in on my side. I was in a couple of fistfights growing up, but never because of racial epithets.

Growing up I had several Navajo friends as well. I was especially close to two Navajo classmates, Margie Curley and Joe Thomas. Both read everything they could find, wrote interesting stories, and had beautiful handwriting. Margie was soft-spoken, but we often had long conversations about our families and interests. Joe, one of my Little League teammates for four years, was one of the most popular children in school. I lost track of Joe and Margie after high school, although I heard later that Margie settled on a reservation and inakes jewelry; apparently neither had the funds to go on to college. I caine to know another Navajo family that traded at our store, the Bendles. I thought the parents were terrific with the children-always using the right annount of discipline, but spoiling them with candy on occasion and consistently assigning responsibility and displaying trust. Hugh Bendle, Jr., became a fine tennis player, and with the help of loans, grants, and Mr. Bendle's savings from his wages as a copper miner, all three of the Bendle children went to college.

My whole family was exposed to and embraced these multiple cultures. My inother ran the grocery store, and since I worked there every day growing up, I retam indelibly-etched memories of her speaking with customers, einployees, salesmen, deliveryinen, and repairmen in both English and Spanish. Unlike my mother, neither of iny two aunts was fluent in Spamish or Enghish, yet both were able to work in their own family stores and interact with our non-Chinese neighbors and custoiners.

My fanily celebrated a variety of holidays-American, Chinese, and Mexican - and soinetimes even traveled to Flagstaff for summertime Native American festivals. We ate a variety of foods at home, mainly Chinese, American, and Mexican. My sisters still cook great Mexican cuisine. Our Mexican customers and neighbors often brought us dishes to sample and my mother reciprocated with some of her own. Every day with dinner we ate Texas Long Grain Rice, ordered specially from a distributor. Another of our customers, a Syrian American family, did the 
same. One German immigrant couple who were also customers often spoke of their native culture and foods.

Many of my high school classmates went to college. Many stayed in Superior and mined copper-just like their parents. Two of my nephews did not go to college, instead staying im Superior to run a large grocery store. The support of my parents (my father completed high school in Chma, my mother a few years of grammar school), iny siblings, and our next-door neighbor Mr. Gonzales, motivated me to go to college. Mr. Gonzales was the most distinguished person I knew. He lived in Washington, D.C., where he worked for Senator Carl Hayden, but he came home a few times a year to visit his Mexican-born mother. When in Superior, he took the time to tell me about his work and encourage me to study hard and go to college.

From what I understand through conversations with friends from rural America, Superior was im many regards a typical close-knit sinall town. High school sports were a central focus. The American Legion, VFW, Knights of Columbus, and Rotary Club all had active chapters. My father was the first president of the Superior Rotary Club and during World War II served as the town sheriff. We attended the Presbyterian Church (without my Buddhist mother), although most of our friends and customers were Catholic. In fact, two of my sisters were christened as Catholics. Superior had other churches as well: Baptist, Episcopalian, Spamish-service Presbyterian, Jehovah's Witnesses, and Mormon. At nineteen my brother Johnny married his high school sweetheart, a Mormon. The mine-mill labor umion was active. My parents extended grocery store credit to union members during lengthy strikes, thus earnmg their loyalty, even though my parents also traded with wealthier management families.

Although I left Superior after graduating from high school to attend college at U.C. Berkeley, my early life in Superior has liad a profound influence on my thinking on multicultural, multiracial, and multireligious communities, class distinctions, and social values. Although things were not always perfect, my family was part of a larger community that respected our Clinese American identity and culture. We learned about and respected other cultures and languages. I found that I could learn values and approaches to life from people of all backgrounds, from my Catholic Mexican American playmates to my Jewish high school history teacher, from Navajo and German customers to the chief administrator of the local mine. The opportunity to hear different perspectives always seemed an advantage.

My life after high school-at U.C. Berkeley, in law sclool, in Chinatown, at the Buddhist churcli, as a legal services attorney, immigration lawyer, academic, participant in community activities, spouse, and parent-lias also sliaped my views. My early life in Superior and my 
subsequent life experiences have created impressions, some would say biases, that lead to views about America and being an American that one might loosely call cultural pluralism. Since recognition of the potential biases created by one's background is a necessary first step in wrestling with the challenge of a multiracial society, I continue to try to make sense of how that past affects my thinking today.

This Article analyzes the positions of assimilatiomsts and cultural pluralists in a debate that not only influences our views towards immigration policies, but also encompasses the very nature of American culture and our normative visions of society. In Part I, I analyze the objections that cultural assimilationists and Euro-immigrationists have about today's immigrants. I find that their positions generally fall into overlapping race-based and culture-based complaints. Part II considers two points that assimilationists seen to overlook, namely that the United States is already a multiracial, multicultural country whose culture is constantly evolving and that today's immigrants actually do acculturate. In Part III, I set forth some modern-day justifications for a plurahisitic approach related to visions of democracy, the economy, and social benefits. In Part IV, I give particular attention to imterethnic group conflict and separatism, two issues which assimilationists often use to frighten the mainstream into supporting immigration restrictions. Despite tactical exaggerations by assimilationists, conflict and separatisnı cannot simply be brushed aside. In Part V, I encourage all of us to consider a new approach to cultural plurahism, which respects diverse views and cultures, which is constantly attentive to race relations, and which shares a common core set of values. In confronting these difficult issues, we need to go beyond the rhetoric of assimilation and cultural pluralism and think seriously about what it means to become an American in an increasingly diverse society.

In their current attack on the influx of Asian and Latino immigrants, interethnic group conflict, and separatism, assimilationists essentially posit two solutions: 1) exclusion or drastic curtailment of immigration; and 2) Americanization of those who are here. ${ }^{16}$ I fundamentally disagree with both the race-specific premise of the assimilationist position that being an American connotes white, Christian, European ancestry and the assimilationist proposals of inimigration exclusion and "Americanization" that are often couched in a rhetoric of culture, but operate in a inanner based on race. ${ }^{17}$ In this Article I set forth niany of

16. The assimilationists' first proposal is to amend existing federal immigration laws to exclude immigrants from Asia and Latin America. See HiNG, supra note 11, at 17-42; infra notes 25, 32-39 and accompanying text. Their second proposal, Americanization, would target those immigrants of color from Asia and Latin America who already reside in the United States and attempt to make them more "American" through the enactment of English-only laws and other provisions. See infra text accompanying notes $40-41,45$.

17. See infra text accompanying notes 18-19. 
my own constantly-evolving notions of cultural pluralism and what it means to be an American.

I set forth a concept of a common, unifying core set of values holding together different groups. This core would include respect for laws, the democratic political and economic system, equal opportunity, human rights, and diversity. This concept does not, however, imply a lack of support for ethnic communities. Ethnic communities are critical in providing a sense of identity, fulfillment, and self-confidence for many. Society should be respectful of those who hold separatist views and prefer to live and work among others of the same background. At the same time, society should strive to eradicate the harmful situations that have led to much separatist sentiment. We cannot expect those at the margin to buy into a core without the commitment of the power structure. Immigrant adaptation, and creating a common core, must be viewed as a dual responsibility of the immigrant and the mainstreain.

\section{I}

\section{RACE AND CULTURE: TODAY's EURO-IMMIGRATIONISTS AND CULTURAL ASSIMILATIONISTS}

When Patrick Buchanan challenged President Bush for the 1992 Republican presidential nomination, an integral part of his "America First" campaign criticized current immigration policies. ${ }^{18}$ Buchanan attempts to couch his attacks in cultural assimilationist terms, but the core of his claims are race-related. To Buchanan, the notion of immigrants retaining their native cultures is ruining America. "[P]ut[ting] America first ... inean[s] our Western heritage is going to be handed down to future generations, not dumped onto some landfill called inulticulturalisı." 19 Given the demographic composition of today's inımigrants, the thrust of Buchanan's assinilation claim collapses into a racial claim because Asian and Latino immigrants, who constitute the majority of today's immigrants, do not coine from a Western European racial or cultural heritage. To Buchanan, retaining this heritage is tantamount to the adulteration and degradation of American culture. Likewise, another 1992 Republican presidential lopeful, former Ku Klux Klan leader David Duke, clains that immigrants "mongrelize" our culture and dilute our values. ${ }^{20}$

Buchanan and Duke are not the only champions of a failure-toassimilate attack on immigration. Senator Alan Simpson, a chief architect of U.S. immigration policy, has written, "Iminigration to the United

18. See supra text accompanying note 1 .

19. John Hanchette, Sharp Tongue, Quick Wit, Could Come Back to Haunt Buchanan, Gannett News Service, Feb. 26, 1992, available in LEXIS, Nexis Library, GNS File.

20. Harry Shearer, Man Bites Town: Our Teeming Shore, L.A. TIMES, Jan. 5, 1992, Magazine at 8 (quoting David Duke). 
States is out of control."21 "[A]ssimilation to fundamental American public values and institutions inay be of far more importance to the future of the United States. . . [A] community with a large number of inimigrants who do not assimilate will to some degree seem unfamiliar to longtime residents."22 In Simipson's view, immigrants must accept the "public culture of the country-as opposed to private ethnic culture."23

Similarly, consider the Federation of Americans for Immigration Reform (FAIR). Touted as the nation's "main restrictionist lobbying group, "24 one meniber of FAIR calls for restricted immigration so that Americans may give theinselves some "breathing space" to perform the "task of assimilation."2s Richard Lamm, a former Colorado governor and chair of FAIR's advisory board, adds, "[America] can accept additional immigrants, but we must make sure they become Americans. We can be a Joseph's coat of many nations, but we must be unified."26 Even some self-described liberals insist that immigrants demonstrate their desire to jom other Americans and become "one of us."27

While the "mainstream" views of Simpson and FAIR resenible the argunients of extremists like Buchanan and Duke, important conceptual differences exist within the rhetoric of failure-to-assimilate complainants. The language of those who rely on assimilation arguments to oppose today's immigration levels can be placed into two sometimes-overlapping categories: 1) race-based objections, and 2) culture-based (i.e., nonracebased) objections. Conventionally, both of these categories might have fallen within the label of "Anglo-conformity" assimilation, ${ }^{28}$ although

21. Alan K. Simpson, Foreword, 20 SAN Diego L. REv. 1, 1 (1982).

22. Select Comm'N on ImMigration \& Refugee Policy, supra note 2, at 412-13 (statement of Commissioner Alan K. Simpson, United States Senator).

23. Steven A. Chin, Asian American Power Tested, S.F. ExAminer, May 26, 1992, at A-6 (quoting Dick Day, Simpson's chief counsel on the Senate Judiciary Committee).

24. Morton M. Kondracke, Borderline Cases, NEw Republic, Apr. 10, 1989, at 8, 9. FAIR describes itself as a "centrist" organization with a membership which includes environmentalists and people with a wide range of political philosophies, including Eugene McCarthy. Telephone Interview with Anna Weinroth, lobbyist for FAIR (Nov. 4, 1991).

25. Hearings Before the Subcomm. on Economic Resources, Competitiveness, and Security Economics of the Joint Economic Comm., 99th Cong., 2d Sess. 397 (1986) [hereinafter Hearings] (statement of Otis L. Graham, Jr., Professor, Center for Advanced Studies, Stanford University).

26. Id. at 359 (statement of Richard D. Lamm).

27. BouviER, supra note 3, at 184-86. In his acknowledgments, Bouvier states, "It has been a rewarding and challenging experience, and in one sense, troublesome as well. Here I am, a selfproclaimed and proud Liberal advocating reduced levels of immigration!" Id. at iii.

28. "Anglo-conformity," along with the "melting pot" and "cultural pluralism," constitute the three main conceptual models of assimilation in the United States. Milton M. Gordon, Assimilation in America: Theory and Reality, 90 DAEDALus 263, 263 (1961). These categories may provide a mere description of the process, or an ideal, or both. The Anglo-conformity model assumes the "desirability of maintaining English institutions (as modified by the American Revolution), the English language, and English-oriented cultural patterns as dominant and standard in American life." Id. at 265. Restrictionists, who were adamantly opposed to a melting pot idea, embraced Anglo-conformity. Their Anglo-conformity aimed to strip the immigrant of homeland culture and "make him over into an American along Anglo-Saxon lines." Leon F. Bouvier \& Robert W. 
given the melding of European immigrants over the years, the term "Euro-American conformity" might be more appropriate. ${ }^{29}$ However, the discourse of today's assimilationists suggests that for many people a distinction exists between racial and cultural factors.

\section{A. Race-based Objections}

Buchanan, Duke, and restrictionist immigration groups such as the Americans for Immigration Control (AIC) advocate a Euroimmigrationist philosophy that favors white, European inımigrants in the behief that they are eaiser to assimilate. ${ }^{30}$ Buchanan's and Duke's statements reveal the racist nature of their approach to inimigration. Their vision for America is white and Christian. ${ }^{31}$ Duke submits, "We've got to begin to protect our values. We've got to begin to realize that we're a

Gardner, Immigration to the United States: The Unfinished Story, 41 Population BuLl. 1, 33 (1986).

The melting pot model is based on the belief that immigrants of all cultures together form a new national character. See Gordon, supra at 271 . I later argue that a de facto sort of melting pot actually occurs today, with the culture of new immigrants constantly affecting the definition and character of the national character. See infra text accompanying notes 47-66.

The term "cultural pluralism" was coined by the philosopher Horace Kallen in the 1920s. In proposing cultural pluralism, Kallen argued that the nation should "consciously allow and encourage its groups to develop democratically, each emphasizing its particular cultural heritage." Bouvier \& Gardner, supra at 33 (quoting Horace Kallen); see also Gordon, supra at 277-78.

The traditional strict assimilationist sentiments merged race and nonrace issues and embodied racial and cultural prejudices. This philosophy has a long heritage. Prior to the arrival of the Chinese in the late 1800 s, some American opinion leaders promoted the melting pot notion of blending races and cultures, although Native Americans and African Americans were excluded from this vision. See Stuart C. Miller, The Unwelcome Immigrant: The American Image of THE CHINESE, 1785-1882, at 192 (1969). However, restrictionists adamantly opposed the melting pot conccpt, embracing instead a cauldron concept of Anglo-conformity. Becoming an American involved stripping the immigrants of their homeland culture in order to make them over "into an American along Anglo-Saxon lines." Bouvier \& Gardner, supra at 33.

This movement, evident as far back as colonial times, see Gordon, supra at 266-67, was fueled by the influential 1911 Dillingham Commission report, see Willi P. Adams, A Dubious Host, WIIsON Q., New Year's 1983, at 101, 107, and a general sentiment exemplified in 1917 by President Woodrow Wilson: "A man who thinks of himself as belonging to a particular national group in America has not yet become an American." Id. at 111. This Anglo-conformity philosophy was part of the foundation for exclusionary laws aimed at Asian immigrants, see HiNG, supra note 11, at 1742, national origins quota restrictions on southern and eastern Europeans, see JOHN HIGHAM, Strangers in the LaNd 316-24 (1955); Edward P. Hutchinson, Legislative History of AMERICAN IMMIGRATION PoLICY 1798-1965, at 180-94 (1981), and the implementation of formal assimilation programs directed at groups such as Mexican immigrants and Native Americans, see infra Appendix A.

29. See Bouvier, supra note 3, at 180 (asserting that, as European Americans gradually gained acceptance by conforming to Anglo norms, "[w] hat had been an Anglo-conformity umbrella had become a European-American umbrella").

30. I use the terms "race assimilationists," "race-based assimilationists," and "Euro. immigrationists" interchangeably to describe Buchanan, Duke, and others who correlate race and immigration.

31. See Buchanan's Venom, Boston Globe, Mar. 6, 1992, at 10. 
Christian society. We're part of Western Christian civilization." ${ }^{32} \mathrm{He}$ says that because of "illegal immigration, ... [o]ur traditions are being torn away. Our values are being torn away." 33 If he is elected, he says, "there won't be any Haitians setting foot on American soil."34 Similarly, Buchanan argues that our heritage is white. "Why are we more shocked when a dozen people are killed in Vilnius than [by] a massacre in Burundi? Because they are white people. That's who we are. That's where America comes from." 35 Central to both Buchanan's and Duke's assertions is the premise that white Christians alone founded and built this nation. Therefore, only white Christians merit entry; only they can be "American." Buchanan and those like him iguore the enormous contributions people of color have made to this country, notwithstanding the suffering and oppression they have endured. ${ }^{36}$ For Duke and Buchanan, new immigrants of color entering the country threaten the nation's racial and rehigious "purity." 37 Thus, to race assimilationists such as Buchanan and Duke, the obvious solution is to enact race-based exclusionary immigration laws.

In the same vein, the right-wing AIC supports the notion that the United States should "consider calling a halt to the mass influx of even more millions of hungry, ignorant, unskilled, and culturally-inorallygenetically unpoverished people." 38 Its spokespersons argue that while "America's apparent decline obviously has multiple causation, a factor of overriding inportance is that its ethnically mixed population no longer rallies around common values to the extent necessary for successful attacks on internal and external problems." 39 The AIC correlates race with adhesion to common values. For them, the failure of certain segments of the American population to rally around a core is a function of

32. Samuel Francis, Wake-up Alarm on Illegal Immigration, WASH. TIMES, Dec. 10, 1991, at F1 (quoting David Duke).

33. Robert Shogan, Duke Will Run Against Bush in Primaries, L.A. Times, Dec. 5, 1991, at A1, A34 (quoting David Duke).

34. Judy Keen, Immigration Fast Becoming Issue for '92, USA ToDAY, Jan. 3, 1992, at 4A (quoting David Duke).

35. A Nasty Campaign of "Us" vs. "Them": Buchanan's Appeal to Voters' Fears, L.A. Times, Mar. 5, 1992, at B6.

36. See generally TAKAKI, supra note 15 .

37. One wonders if Buchanan and Duke would permit non-English-speaking white Europeans to immigrate, since both are concerned with insuring the monopoly of English. Professor Stephen Carter points out that "Mr. Buchanan might be surprised at how many Zulus in multi-lingual South Africa speak better English than most of the Europeans of whom he is so enamored." Stephen $L$. Carter, Nativism and Its Discontents, N.Y. TIMES, Mar. 8, 1992, at E15.

38. Environmentalist Hits Immigration, IMMIG. WATCH (Americans for Immigration Control, Monterey, Va.), Oct. 1989, at 8 (quoting American environmentalist Edward Abbey).

39. Chilton Williamson, Jr., The Right Books, NAT'L REv., Apr. 21, 1989, at 48, 48 (reviewing Glaister A. Elmer \& Evelyn E. Elmer, Ethnic Conflicts Abroad: Clues to America's FUTURE? (1989) and quoting therefrom). 
race and ethnicity. To preserve cultural cohesion, immigration laws must control the race and ethnicity of entering immigrants.

\section{B. Culture-based Objections}

The assimilationist position that raises cultural objections may not be couched in racial language. Assimilationists often express their alarm over the recent increase in non-Enghsh speaking immigrants in nonracial terins. Governor Lamm of FAIR, which has had a siguificant leadership overlap with the English Only movement, says, "We inust have English as one of the common threads that hold us together. We should be color blind, but we can't be linguistically deaf."40 Senator Simpson feels that "if hinguistic and cultural separatism rise above a certain level, the unity and pohtical stability of the nation will im time be seriously eroded."41 The cultural assimilationist rhetoric of FAIR complains that "largescale" immigration lowers American living standards and dilutes American culture. ${ }^{42}$

While this culture-based argument studiously avoids race and etlinicity, the inplications of tlie argument are distinctly race-based. Given the huge numbers of imimigrants who enter this country from Asian and Latin American countries whose citizens are not white and who in most cases do not speak English, criticism of the inability to speak English coincides neatly witlı race.

Moreover, the presence of nonwlite immigrants in the United States threatens cultural umfornnity because the immigrants bring with them their own languages and cultural practices. Many cultural assimilationists believe that large-scale Latno and Asian imnigration contributes to an increasingly bilingual society, ${ }^{43}$ creates substantial probleuns in schools, and clianges our national identity in unwelcome ways. Social, political, and cultural issues are now "uppermost in the minds of many Americans concerned about the consequences of inimigration." 44 Englisli-only initiatives liave become increasingly common, ${ }^{45}$

\footnotetext{
40. Hearings, supra note 25 , at 359 (statement of Governor Richard D. Lamm).

41. Select Comm'N ON Immigration \& Refugee Policy, supra note 2, at 413 (statement of Commissioner Alan K. Simpson, United States Senator).

42. See Dan Stein, The New Americans, Economist, June 22, 1991, at 6 (letter to the editor).

43. See Hearings, supra note 25, at 370-73 (statement of Governor Richard D. Lamm); Thomas Muller \& Thomas J. Espenshade, The fourth Wave: California's Newest IMMIGRANTS 187 (1985).

44. MUller \& EsPENSHADE, supra note 43, at 187.

45. Nineteen states have given English official legal status. See Update on Legal Official Recognition of English in Missouri, Louisiana, U.S. NEwSWIRE, Mar. 6, 1992, available in LEXIS, Nexis Library, USNWR file. Endorsements of the exclusive legitimacy of English have been passed at either the state or local levels in a number of states, including Califomia, Arizona, Colorado, and Virginia. See Sanford Levinson, Lingo Fracas, 255 NAtion 549, 550 (1992). Seventy years ago, the Supreme Court upheld an analogous Nebraska statute making English the language of instruction in elementary schools. See infra text accompanying notes 199-200.
} 
and their advocates voice the following sentiments:

Summer has ended and school bells are ringing once again. But what will your children or grandchildren learn in our schools this year? ... [T] hey may soon be taught that America is a hateful place founded by racists and inurderers. Or that holidays like Columbus Day or Thanksgiving celebrate genocide and slavery and should be banned ... [or] that they are descendants of the European "ice people" whose lack of skin color identifies thein as inferior race! . . . Many of these educational "experts" are also behind the drive for so-called "bilingualism." I put it in quotes because these people really want to do away with Enghish and everything European.... America has a language, a history and a culture. It does not want or need to import others. For two hundred years immigrants have come to our shores looking for soinething better than what they were leaving behind. ... They neither expect nor want America to turn itself into a banana republic so they can feel inore at home. ${ }^{46}$

Underlying this ferocious rhetoric is the fear that immigrants will leave their nonwhite mark on the American landscape: that there will be revisionist histories outlining the full story of how America developed through genocide, slavery, oppression, imperialism, and expansionism as well as through commitment to independence, justice, and individual rights; that our language will expand to include new terms and idioms, not all of which have an Anglo-European pedigree.

At bottom, cultural assimilationists envision an America in as narrow and racially exclusive ternns as do the race assimilationists such as Buchanan and Duke. Despite the difference im diction and approach, both groups share the saine philosophical race-based core. They believe that the United States has a Western-European cultural heritage that inust be inaintained, and that current levels of iminigration threaten to alter or dilute that culture. This concern for "our" culture and heritage is the essential norinative premise of cultural assimilationists and Euroinmigrationists.

Nonetheless, the distmction between the Euro-imnigrationists' racist rhetoric and the cultural assimilationists' cries for preserving the Enghish language and American culture serves an inportant purpose. It allows us to dismiss the racist, inflamınatory rhetoric of people like Patrick Buchanan and David Duke as the views of politically expedient extrenists and to begin the task of seriously examining the issues behind the rhetoric of both the cultural assimilationists and cultural pluralists.

46. Memorandum from Gary Rubin \& Frank Sharry, National Immigration, Refugee \& Citizenship Forum, to Forum Members \& Colleagues (Apr. 1, 1992) at 3 (quoting George Tryfiates, Executive Director, English First) (on file with author). 
II

\section{ACCULTURATION AND THE EVOLUTION OF AMERICAN Culture}

In this Section I will address the flaws of the Euro-immigrationist and cultural assimilatiomist positions. These flaws can be merged into two general propositions. The first is the essentially normative premise that America has a strictly white, Christian, European heritage. The second proposition of the Euro-immigrationists and cultural assimilationists is their misguided claim that immigrants of color fail to acculturate.

\section{A. America's Multiracial and Multicultural Heritage}

While Buchanan and others dismiss multiculturalism as "landfill,"47 multiculturahism challenges the premise that America is a white, Enghish-speaking, Western Christian nation. Not only did Native American tribes long pre-date the arrival of white Christians, but the early European settlers spoke Spanish, German, Dutch, French, and Pohsh in addition to Enghsh. ${ }^{48}$ Before Chinese exclusion laws became permanent near the turn of the twentieth century, about 300,000 Chinese had entered the country. ${ }^{49}$ Filipinos established a community in Louisiana as early as $1565 .^{50}$ Spanish-Portuguese Jews, the Sephardim, settled in the New World in the mid-1600s. ${ }^{51}$ Mexicans, initially propelled by Mexico's historical territorial claims in the Southwest, have long-established patterns of migration to the United States. ${ }^{52}$ Over 9.5 million Africans were captured and brought to the western hemisphere as slaves. ${ }^{53}$ In the first decade of this century, about 2 million Italians, 1.6 million Russians, and 800,000 Hungarians immigrated. ${ }^{54}$ In short, the heritage of the United States does not derive solely from people who are white, English-speaking, Christian, and European. Nonwhite peoples have a long history in America, most of which is unflattering to the white, European Christians that Buchanan and Duke extol. The genocide of Native Americans, brutal enslavement of African Americans, and exploitation and oppression of Asian and Latino Americans are harsh reminders of our nation's past. In spite of the oppression, people of color

47. Hanchette, supra note 19.

48. Diego Castellanos, A Polyglot Nation, in Language Loyalties: A Source Book ON THE Official ENGLish Controversy 13-18 (James Crawford ed., 1992).

49. HING, supra note 11 , at 48 tbl. 3.

50. Id. at 61 .

51. Castellanos, supra note 48 , at 15 .

52. Alfredo Mirande, Gringo Justice 100-16 (1987); Gerald P. López, Undocumented Mexican Migration: In Search of a Just Immigration Law and Policy, 28 UCLA L. REV. 615, $641-72$ (1981).

53. See John hope Franklin, From Slavery to Freedom: A History of Negro AMERICANS 59 (3d ed. 1967).

54. 1990 INS STAT. Y.B., supra note 13, at 49 tbl. 2. 
have contributed to America's history and development and are a vital part of its heritage.

\section{B. Immigrant Acculturation}

While the race assimilationists tend to focus on the theory that America is a white, European-based society which should stay that way, the culture-based critics of immigration tend to focus on acculturation. Much of the Simpson, Lamm, and FAIR arguments consist of complaints that immigrants fail to absorb American culture. Study after study demonstrates, however, that the vast majority of immigrants take on cultural traits of the host commumity. Some traits are taken in exchange for, but most are taken in addition to, old ones. ${ }^{55}$ For example, immigrants entering the United States today learn English at the same rate as other immigrant groups before them. ${ }^{56}$ First generation immigrants tend to learn Enghish and pass it along to their children, who become bilingual. ${ }^{57}$ Immigrants want and encourage their children to learn Enghish. By the third generation, the original language is often lost. $^{58}$ Throughout the Uinted States, the demand for English as a Second Language (ESL) training far outstrips supply, leading adult newcomers to encounter long hines and waitmg lists before gaining access to classes. $^{59}$

The Latimo commumity, in particular, is frequently accused of not assimilating and not learning English. ${ }^{60}$ Yet Spanish-speaking immigrants who have been in the country for fifteen years regularly speak English. ${ }^{61}$ They usually read English fluently withm ten years. ${ }^{62}$ In addition, about ninety-three percent of all Mexican inınigrants agree that residents of the United States should learn English. ${ }^{63}$

55. See infra Appendix B for a brief discussion of studies on the actual assimilation process of immigrants.

56. See Frank Sharry, Why Immigrants Are Good for America, OrLANDo Sentinel, Sept. 22, 1991, at G1, G5.

57. See Lawrence Kutner, Parent \& Child, N.Y. Times, Nov. 19, 1992, at C12 (describing an Armenian immigrant's bilingual childhood and pointing out that "many children who were raised speaking a different language often feel considerable pressure to speak only English at school and in public"); Sharry, supra note 56, at G1, G5.

58. See Sharry, supra note 56, at G1. In my experience, I have never met an immigrant family that discouraged its children from learning English.

59. Interview with Maria Monet, San Francisco Community College Board of Trustees, in San Francisco, Cal. (Mar. 9, 1993); see also Ashley Dunn, Immigrants Protest English Class Cuts, L.A. TIMES, June 19, 1991, at B3. Many immigrants, embarrassed by their "accents," have turned to private English diction lessons. See Raymond Hernandez, Immigrants Use Diction Lessons to Counter Bias, N.Y. TIMES, Mar. 2, 1993, at A12 (national edition); Tracy Wilkinson, An Accent Could Be an Invitation to Bias, L.A. TiMEs, Apr. 23, 1991, at B1.

60. See Sharry, supra note 56, at G5.

61. Id.

62. Linda Chavez, Tequila Sunrise: The Slow But Steady Progress of Hispanic Immigrants, Heritage Found. Pol'y ReV., Spring 1989, at 64.

63. Roberto Suro, Hispanic Pragmatism Seen In Survey, N.Y. TIMEs, Dec. 15, 1992, at A20. 
Although complete acculturation of all immigrants is impossible, immigrants and refugees of all ages becomc acculturated to some extent. Even before coming to the United States, sonie adult inimigrants and refugees have been exposed to American culture due to its pervasiveness in the global media. Upon arriving in the United States, nost adult inmigrants and refugees work, learn English, and often strive to pick up U.S. cultural habits and customs. Many young Asian and Latnio immigrants, in particular, aggressively strive to be "American." They are eager to learn English, to get a job, to work hard; in short they seek to achieve a part of the American dream. ${ }^{64}$ Their aspirations are similar to the ones that notivated Jewish, Irish, and Southern and Eastern European immigrants in earlier years. Due to school attendance, interaction with peers, and exposure to the media, the children of immigrants, even those who are foreign-born, generally beconie fully acculturated. These children speak English, and their customs, habits, and values are nearly indistimguishable from those of their peers.

In addition to complaining that new immigrants fail to adopt our society's cultural traits, cultural assimilationists also contend that inimigrants threaten to dilute our Western cultural lieritage. Whatever normative perspective one takes on the subject, the fact is that imnigrants do affect our culture, perhaps as much as our culture affects theni. As immigrants acculturate, their custonis, cuisine, interests, and values are absorbed to some extent by the larger U.S. society. ${ }^{65}$ Our culture and our definition of what it means to be American is ever-evolving. Once here, immigrants help create that definition. ${ }^{66}$

Changes in U.S. culture are, of course, not solely nor even mainly

64. See, e.g., Latinos as They See Themselves, Plain DeAlen, Dec. 17, 1992, at 10B ("Even among those on the margins of society we found a desire to gain access to mainstream America.' Just like earlier waves of immigrants from elsewhere.") (quoting Rudolpho O. de la Garza).

65. Absorption of the foods, music, and even the vocabulary of immigrants into "American" society is most common. A recent survey by the National Restaurant Association found that $25 \%$ of non-Latino consumers consider Mexican to be their favorite ethnic food and $41 \%$ of non-Latino people had eaten Mexican food within the last month of the survey. In 1991, salsa outsold ketchup in the United States. Calvin Sims, Tortillas Gain Aficionados in U.S., N.X. TIMES, Sept. 23, 1992, at DI, D5.

66. In the same vein, Henry Louis Gates regards African American culture as a "model of multiculturalism and plurality":

Duke Ellington, Miles Davis, and John Coltrane have influenced popular musicians the world over. Wynton Marsalis is as comfortable with Mozart as with jazz. Anthony Davis writes in a musical idiom that combines Bartok with the blues. In the dance, Judith Jameson, Alvin Ailey, and Katherine Dunham all excelled at "Western" cultural forms, melding these with African-American styles to produce performances that were neither, and both. In painting, Romare Bearden and Jacob Lawrence, Martin Puryear and Augusta Savage, learned to paint and sculpt by studying Western artists, yet each has pioneered the construction of a distinctly African-American visual art. And in literature, of course, the most formally complex and compelling black writers-such as Jean Toomer, Sterling Brown, Langston Hughes, Zora Hurston, Richard Wright, Ralph Ellison, James Baldwin, Toni Morrison, and Gwendolyn Brooks-have always blended forms of Western literature with African-American vernacular and written traditions. Then again, even a vernacular form like the spirituals took as its texts the King James version of the Old and 
attributable to the influence of immigrants. Improved technologies, social movements, and economic developments are also crucial. However, there does exist a melting pot of sorts. Immigrants do not displace American culture, but they help develop a distinctively new and constantly evolving and expanding U.S. culture.

\section{III}

\section{A Modern Day Vision of Cultural Pluralism: MUlTiCUlTURALISM AND ASSimilation BY CHOICE}

In contrast to the assimilatiomist approach, cultural pluralism focuses on the benefits brought by immigrants. In the historical dispute over immigration policy and assimilation, liberal intellectuals challenged the Anglo-conformity approacli witl a model of cultural pluralism which actually encouraged ethnic groups to retain their cultural lieritage. ${ }^{67}$ Ethnic enclaves such as Little Italys and Chinatowns exemplify such preservation. Cultural pluralists envisioned that, while native cultural patterns could be preserved, the groups would continue to evolve as Americans and would eventually take part in democratic institutions. ${ }^{68}$

Historically, cultural pluralism was not diametrically opposed to assimilationism. In fact, cultural pluralists believed that English should be the common language and that all citizens should share and participate in the general society's political and economic life. For pluralists, this seemed to represent a common core of values. ${ }^{69}$ The minimum expectations of Enghish language competence and acceptance of the nation's political and economic frainework on the part of immigrants were important assumptions shared by both assimilationists and cultural pluralists. This, however, was where the similarities ended.

Cultural pluralists believed that each nationality and ethıric group should retain its own individuality in language, religion, and culture. ${ }^{70}$ Promoting an early version of bilingualism and biculturalism, they felt that both immigrants and minority groups liad a right to preserve their primary identities; they msisted on the value of the ethnic group "as a

New Testaments. Morrison's master's thesis was on Virginia Woolf and Faulkner; Rita

Dove is as conversant with German literature as she is with that of her own country.

Henry L. Gates, JR., Loose Canons: Notes on the Culture Wars xvi-xvii (1992). Similarly, Asian American writers such as Maxine Hong Kingston and Frank Chin blend two cultures into a distinct American product, as do Latino writers such as Sandra Cisneros and Luis Valdez.

67. See Alexander SAXton, The Indispensable ENEMY: LABOR ANd the ANTIChinese MOVEMENT IN CALIFORNIA 103 (1971); Bouvier \& Gardner, supra note 28, at 32; Gordon, supra note 28, at 277-78; Horace M. Kallen, Democracy Versus the Melting Pot: A Study of American Nationality (pt. 2), 100 Nation 190, 217 (1915).

68. See Gordon, supra note 28 , at 274-77.

69. I discuss my own vision of common core values infra Part V.C.

70. See Raymond A. Mohl, Cultural Assimilation Versus Cultural Pluralism, in Assimilation, Acculturation, AND Social Mobility 187, 192 (George E. Pozzetta ed., 1991). 
permanent asset in American life."71 The pluralists suggested that each ethnic group should be permitted a communal life, "preserving and developing its cultural heritage while at the same time participating effectively in the broader life of the nation as a whole."72 Pluralists accepted the disintegration of ethmic groups and their subsequent assimilation into American life as long as it resulted from the free choice of individuals and not from coercion..$^{73}$

Although it needs refinement, much of the historical cultural pluralist paradigm remains valid today. ${ }^{74}$ Many, myself included to a degree, subscribe to these conventional views of cultural pluralism and dismiss the concerns of cultural assinilationists as well as the racism of Buclianan and Duke. In celebrating multiculturalisin, ${ }^{75}$ we offer our own rhetoric, arguing that "[a] rambunctious America is a strong America,"76 and tliat "[d]espite the costs-and even the pain-that may be caused by inmigration, the benefits are incalculable."77 There is, moreover, substance behind the rlietoric: there are real advantages to pluralisin.

\section{A. Constitutional Principles}

One of the strengths of cultural pluralism is its connection to constitutional principles. Some of the central tenets of liberal deınocracy-the principles of religious freedom, freedom of speech and assembly, and privacy-encourage and protect diversity. We pride ourselves in inaintaining and exercising these constitutional riglits, and they are a major reason so many people seek U.S. residency and citizenship.

Promoting and maintaining one's own etlinic culture-a fundainental premise of pluralism-is therefore consistent with constitutional prin-

71. Id. at 192 (citation omitted).

72. Id. (citation omitted).

73. See id. at 193.

74. I suggest a new approach to pluralism infra Part V.

75. Essayist Roger Rosenblatt suggests that

America is only America because the country is black, white, tan, beige, yellow, red, pink and all shades not accounted for. What would happen if the bigots got their wish is that we would be stuck in a country unrecognizable to ourselves. To be sure, an all whitc America would be recognizable to the bigots, but then they would be stuck with themselves, a punishment they probably deserve. The rest of us would have to get out of here, go off in search of a new world, where differences make strength.

MacNeil/Lehrer Newshour (WNET television broadcast, Jan. 14, 1992). Author Ellis Cose submits: Certainly America is in the process of assembling an array of ethnicities and races unlike anything previously assembled. And if we are wise, we will choose to make that a virtue. We will realize that the differences various groups bring to the table represent a potential gold mine of fresh ideas, if only we can learn to be open to them.

Ellis Cose, a Nation of Strangers: Prejudice, Politics, and the Populating gF AMERICA 218 (1992).

76. Tom Peters, On Excellence-Give U.S. Chaos or Give It Stagnation, CHI. Trib., Apr. 9, 1990 , at B11. 29.

77. William Broyles, Jr., Promise of America, U.S. News \& WoRLd REP., July 7, 1986, at 25, 
ciples. Not only do individuals possess a broad zone of autonomy regarding how they think, speak, worship, and behave, but the government is prohibited from endorsing any one religion or pohtical orthodoxy as "correct."78 The liberal system, aside from controlling substantive subversion (actual violence, disobedience of valid laws, etc.) arguably is prohibited even from proclaiming itself the "best" or only "correct" system. By preserving the "marketplace of ideas," our systein protects those who choose to promote their own ethnic culture.

These traditional hiberal principles suggest that government should not deinand that immigrants subscribe to any particular language or cultural norin any more than to any particular religion. Rather, the ideological principles of the U.S. system require a hands-off, laissez-faire attitude toward shifting cultural boundaries and attitudes. Liberal democrats may desire that new immigrants assimilate into a certam image, but the process is left to inarket forces rather than state intervention.

Historically, however, the Supreme Court and Congress have acted at times in ways that conflict with these principles. The Supreme Court has espoused assimilatiomist thought in several opimions. In Reynolds $v$. United States, ${ }^{79}$ the Court seemed to support the establishnient of a Protestant hegemony by sustaining state anti-polygamy laws; the decision reflected "both a tolerance for the legislative efforts at regulating custom and morality, and a distinct preference for European observances." 80 In United States v. Joseph ${ }^{81}$ the Court felt that because Pueblo Indians held land in fee and had adopted agriculture and Christianity, they had become so advanced, enlightened, and civilized as to escape the confinements of Indian status. ${ }^{82}$

Congress, meanwhile, helped institutionalize the assimilatiomist position through the enactment of restrictive immigration laws in place

78. Dean Paul Brest puts it this way:

It is a truism that we are socially constructed beings-defining ourselves and being defined by others in terms of myriad characteristics, including nationality, national origin, race, ethnicity, religion, gender, and sexual orientation, among others. However much or little freedom individuals actually have to choose and change their identities, it is a strong norm of our society that governments, employers, and most public and private institutions should not coerce or constrain such choices. This norm is, for example, embodied in the establishment and free exercise clauses of the first amendment to the Constitution, and in the antidiscrimination principle embodied in the equal protection clause of the fourteenth amendment. It finds voice in state and federal antidiscrimination legislation that applies to private employers, landlords, and organizations.

Paul Brest, "Diversity" for Whom?, Presentation at the Stanford Law Review Symposium on Civic and Legal Education (Mar. 6, 1993) (manuscript at 14-15, on file with author).

79. 98 U.S. 145 (1878), overruled by Thomas v. Review Bd. of Ind. Employment Sec. Div., 450 U.S. 707 (1981).

80. See John W. Ragsdale, Jr., The Movement to Assimilate the American Indians: A Jurisprudential Study, 57 UMKC L. REV. 399, 416 (1989).

81. 94 U.S. 614 (1877), overruled by United States v. Sandoval, 231 U.S. 28 (1913).

82. See Ragsdale, supra note 80 , at 416 . 
from 1882 to $1965 .^{83}$ These provisions specifically establislied racial categories of immigrants who were barred from entering the United States. The Supreme Court upheld these provisions under Congress' plenary power over aliens. ${ }^{84}$ McCartlyy-era ideological-based exclusion provisions, which were not eased until recently, ${ }^{85}$ also conflicted with liberal democracy. While Congress still may have the power to implement new assimilationist provisions, such actions today would be viewed as regressive. ${ }^{86}$

\section{B. Economic Diversity and Competition}

One argument advanced in favor of assimilation is that efficiency and competitiveness in the world marketplace demand a common national culture and language. This proposition is misguided. A multicultural Umited States provides many advantages in the increasingly interdependent global economy.

Even casual attention to events of the last five years has tauglit us that political and economic developments all over the world-in Europe, Latin America, Africa, Asia, and the Middle East-affect the United States economy. The Dow Jones, interest rates, production, the dollar's value, and economic growth all reacted to democracy movements in Asia and Eastern Europe, the Persian Gulf War, and economic problems in Brazil and Mexico. Certainly the United States will remain economically linked to Europe, but Europe is only one of many regions which are vital to our economy. The blinders of a Euro-centric view of America limit our vision and viability in the international economic community. There are simiply too many cultural differences that have to be considered for the United States to be effective globally. The econoiny increasingly demands expertise in more than American or Euro-centric ways and customs.

83. See HING, supra note 11 , at 17-42.

84. See, e.g., Chae Chan Ping v. United States (The Chinese Exclusion Case), 130 U.S. 581 (1889).

85. The law continues to allow the exclusion of aliens who have been members of or affiliated with "the Communist or any other totalitarian party." 8 U.S.C.A. $\S 1182(a)(3)(D)$ (i) (West Supp. 1993). However, changes made in 1990 (1) eliminated the exclusion for nonimmigrants; (2) provided that immigrants who terminated membership or affliation two years prior to applying for admission are not excluded; and (3) installed a waiver of excludability for a current party member who has a close family member lawfully in the United States. See 2 CHARLES Gordon \& STANLEY Mailman, Immigration Law and Procedure § 61.04(4)(d) (1993).

86. Congress' authority to legislate in the area of immigration has been deemed plenary. See, e.g., Fiallo v. Bell, 430 U.S. 787, 792 (1977) (asserting that " "over no conceivable subject is the legislative power of Congress more complete than it is over' the admission of aliens") (citations omitted). However, modern commentators regard the race-based Chinese exclusion laws of the 1880 s to be based on a principle that "emerged in the oppressive shadow of a racist, nativist mood a hundred years ago" and is a "constitutional fossil." Louis Henkin, The Constitution and United States Sovereignty: A Century of Chinese Exclusion and Its Progeny, 100 HARv. L. Rev. 853, 862 (1987). 
Since Asia and the industrializing nations of Latin America are new areas of economic power and significance, bicultural and multicultural U.S. residents will prove imvaluable as American companies develop private trade agreements and cooperative business ventures with the nations and corporations of these regions. Many businesses, advertising agencies, and law firms already have recognized the benefits of taking a multicultural approach in their Latin American and Asian endeavors. Soine have estabhished branches abroad, most have invested in culture and language traming for employees, and even more have hired bicultural employees. In the age of jet travel, E-mail, and fax inachines, multicultural businesses are engaged in daily transactions in Tokyo, Singapore, Hong Kong, Manila, Beijing, Mexico City, Brasilia, and Caracas as well as London, Paris, and Frankfurt.

\section{The Advantage of a Diverse Work Force in Domestic Markets}

A diverse work force is an advantage doinestically as well. As the ethnic inakeup and deinographics of the country change, smart business managers make changes and innovations in response to the needs of the changing population. In short, responding to demographic changes can help increase profits. However, producing commercials with slogans like "sé habla español" and advertising in the Asian Yellow Pages in order to attract new business inust be coupled with the cultivation of a staff that can develop a rapport with the new custorners. Thus, inore and more einployers are coming to view diversity as good business as well as good public relations.

For exainple, the success of an AT\&T service called Language Line, which allows companies in the United States to cominunicate with their non-English speaking customers and business contacts, illustrates the benefits of a diverse work force. ${ }^{87}$ Through a staff of interpreters on conference calls, Language Line allows businesses such as Whirlpool, Lands' End, Pepsi, and Gerber to commuricate with U.S. and foreign custoiners who do not speak English. ${ }^{88}$ As the director of communications for the service explains, "Business is beginning to appreciate there are over 30 million people in this country who prefer to use a language other than English . . . . The U.S. business community is becoming increasingly attuned to the fact that not every customer speaks English."89

Moreover, the gains from a diverse work place are also independent of the changing demographics. A diverse work place is also a inore innovative work place. For example, Burger King has implemented diversity and inulticultural training semmars for its employees while increasing the percentage of people of color in its work force froin twelve percent in

87. See Jim Cole, Breaking the Language Barrier, S.F. ExAMINER, Apr. 18, 1993, at E1.

88. Id. at E1, E7.

89. Id. at E7 (quoting Michael Cuno, Director of Communications, AT\&T Language Line). 
1986 to twenty-eight percent in $1991 .^{90}$ At Burger King and other businesses that have sought diversity, there is "a growing sentiment that diverse employee teams tend to outperform homogeneous teams of any composition .... [H]omogeneous groups may reach consensus more quickly, but often they are not as successful in generating new ideas or solving problems, because their collective perspective is narrower."91 Thus, the old adage that "two heads are better than one" holds true, except that the more appropriate phrase might be "multiple ethnic perspectives are better than one."

\section{Other Benefits of Cultural Diversity}

Cultural pluralists rightly argue that, as in the past, the country continues to benefit from new immigrants. Although many question the economic benefit of immigrants, ${ }^{92}$ new immigrants, like their predecessors, have the drive and willingness to make a better life for themselves and their families. As a class, immigrants and refugees could very well represent the most determined class of people from their sending nations. ${ }^{93}$ Many have had to survive treacherous journeys and overcome severe obstacles. All have had to demonstrate the courage and fortitude needed to follow through on the difficult decision to uproot themselves and often their families and wind their way through immigration mazes and the logistical facets of relocation. If there is any truth to the charges of laziness and lack of drive in our native work force, we stand to learn and to

90. See Lena Williams, Companies Capitalizing on Worker Diversity, N.Y. Times, Dec. 15, 1992, at A1, D20.

91. Id. at D20 (quoting Robert L. Lattimer, Managing Director, Diversity Consultants, Inc.)

92. Too often, anti-immigrant rhetoric can divert attention and obscure the more salient and relevant issues of economics, class, and the inequitable distribution of resources and tax burdens. For example, California Governor Pete Wilson has blamed much of California's economic woes on immigrants, claiming that they go on welfare and take up seats in public schools. One must wonder whether enormous layoffs in the defense, high tech, and biotech industries may have more to do with the recession than immigrants. See, e.g., Phil Angelides, Wilson's Aim is Job-Saving-His Own, L.A. TIMEs, Dec. 15, 1991, at E1; David Broder, Recession Catches State in a Double Bind, CHI. TRIB., Nov. 17, 1991, at 3; Douglas P. Shuit and Patrick J. McDonnell, Calculating the Impact of California's Immigrants, L.A. TIMES, Jan. 6, 1992, at A1.

93. One commentator writes:

Contrary to our fears of immigration draining our nation's economy, the truth is that immigrants infuse us with new life, giving more than they take. ... [N]ew immigrants contribute more in taxes than they consume in public services. Within ten years after arriving in this country, they pass native-born citizens in earning power and their children overtake those born in the United States in academic achievement.

Thomas Bentz, New Immigrants: Portraits in Passage 186 (1981). Moreover, immigrants today share distinctive characteristics with immigrants of the past:

Those who seek our shores today are not different. They may come from different places on the globe, but their reasons for coming are strikingly similar to the reasons our ancestors came. Even people who escape penniless from hunger or terror bring with them something of value. They, like the pioneers of old, have determination and courage to overcome hardships. They bring knowledge, creativity, ideas and industry which will reinforce or improve the fiber of a free nation.

Theodore M. Hesburgh, Preface to BENTZ, supra at ix, x. 
benefit from the hard work ethic of the immigrants and refugees who continue to enter.

More generally, immigrants represent a potential resource for adding to, rather than diluting, American culture. While the United States continues to be an mnovative leader im many business, pohtical, scientific, and social fronts, it is not the sole innovative leader in all these realms. We should be open to new ideas from people of different cultures who inay have better ways of approaching the gamut of issues facing us, including business operations, protection of the environment, stress, interpersonal relations, and education. ${ }^{94}$

The ultinate benefit from interaction with those of different cultures does not necessarily flow from learning about new innovations, however. Rather, by learning about other cultures through social interaction with people of other cultures, we begin to learn more about other people. We begin to understand their custons, attitudes, and values, as well as to share information about our own cultures. In that process, we begin to develop tolerance and respect for other cultures and backgrounds. This type of education provides the foundation for a peaceful, productive pluralism that must be fostered throughout the world. ${ }^{95}$

\section{IV}

The Challenge to Cultural Pluralists: InterETHNIC GROUP CONFLICT AND SEPARATISM

Some nations encourage the development of more than one culture and, in the process, lose some sense of community. Canada

94. It takes little effort to think of the contributions of immigrants and refugees, such as mathematician and physicist Albert Einstein, computer giant An Wang, architect I.M. Pei, Nobel Laureate Yuan-tse Lee, educator Jaime Escalante of Stand and Deliver fame, and countless others in the arts, theater, sciences, and business. Consider, too, the following citizenship lesson provided by lesser known immigrants and refugees:

Immigrants are not only interested in their own success. They also give us valuable lessons in responsible citizenship. In a Honolulu murder trial last year, all threc key witnesses for the prosecution were immigrants. Eyewitness Sui Fong Ngai, a Hong Kong native, testified to what she saw when her boss was slain. The second witness, Zbysek Kocur, had fled Czechoslovakia in 1968. When deputy prosecutor Archibald Kaolulo thanked him, Kocur said, "For what? This is expected of me." And the third witness, Ahmed Rehman, a Pakistani, identified the gunman, after two men had approached him on his way into the courthouse foyer and told him to change his story. Rehman said, "That only made me more determined to testify."

In a nation where most citizens will watch crimes but do nothing to stop them, the courage and determination of [these immigrants] is truly remarkable.

BENTZ, supra note 93 , at 187 .

95. Assimilationists who fear the social challenge represented by immigrants should be mindful of the fact that the United States is confronted with much diversity that has little to do with immigration. Differences in class, social status, age, religious beliefs, political values, gender, and sexual orientation also represent challenges to the conventional vision of white Anglo-conformity Americanization. Diversity engenders challenges. Immigrants have always been a part of that challenge, but not the sole or central feature. Immigration ought not be the scapegoat for the challenge that diversity in general presents to the nation. 
is such a nation. There, both the English and the French cultures are deemed equal. Embattled Yugoslavia presents an extreme example. It has two alphabets, three major religions, four major languages, five major nationalities, and until recently, was divided into six major republics. One can legitimately inquire: "What is a Yugoslavian?" Canada, Yugoslavia, Belgium and sundry other countries differ enormously from countries like Japan and Sweden where cultural diversity is minimal and a sense of community is resent [sic]. Multilingual countries often exhibit a tendency toward disintegration. The current situation in the Soviet Union is perhaps the most extreme example of such a situation.

Too many countries have failed to attain true national consciousness because of bilingual and even multi-lingual controversies. In so many instances, the ethnic minority identifies first with its own subculture rather than the national culture. . . . Canada has experienced considerable difficulty in getting all of its citizens to be "Canadians." Many residents of French-speaking Quebec call themselves "Québecois" first, and "Canadiens" second. ${ }^{96}$

In addition to fearing that current levels of immigration threaten to alter our western cultural heritage, Euro-immigrationists and cultural assimilationists share two beliefs that are not as easily dismissed by cultural pluralists: (1) that racial and ethnic conflicts have resulted from changes in the racial and ethnic character of the country, since the amendments to immigration laws in 1965 permitted so miany nonEuropean immigrants to enter; ${ }^{97}$ and (2) that these changes foster linguistic and cultural separatism which could threaten "the unity and political stability of the nation."98 The race-assimilationist AIC insists that "[n]o one cause of American institutional disarray is more important than ethnic conflict."99 To Buchanan, ethnic conflict is why "America [is] so vulgar and coarse, so uncivil and angry." 100 He signals a warning by pointing to hostile relations between African Americans and whites:

Look over our country's history. . . . Dred Scott. Gettysburg. Brown vs. the Board of Education. Watts. [And now South Central Los Angeles.] These are all about our effort, successful by and large, but still failed, to assinilate into our society that 10 or 12 percent of Americans who are Afro-Americans. It has been a

96. Bouvier, supra note 3, at $183,188$.

97. John A. Farrell, Open Doors/Closing Minds, Boston GloBe, Feb. 23, 1992, at 61, 63 (quoting Patrick Buchanan).

98. Select Comm'N on Immigration \& Refugee Policy, supra note 2, at 417 (statement of Commissioner Alan K. Simpson, United States Senator).

99. Williamson, supra note 39, at 48 (quoting ELMER \& ELMER).

100. Farrell, supra note 97, at 63 (quoting Patrick Buchanan). 
very, very difficult thing, and we've had great turmoil and a civil war over it. ${ }^{101}$

The more culture-conscious Senator Simpson fears that "[i]f imımigration is continued at a high level and yet a substantial portion of the newcomers and their descendants do not assimilate, they inay create in America some of the same social, political and economic problems which existed in the country which they have chosen to depart."102

Cultural pluralists cannot ignore the issues of intergroup conflict and separatisin. Despite the very real excesses of the assmilationist view, cultural pluralists are hard-pressed to dispute the serious interethnic group conflict and separatist sentiment among immigrants and other groups of color. The Buchanan, Duke, and AIC position that the influx of non-Enghish speaking immigrants of color dooms our culture as we know it to destruction is exaggerated. As we have seen, the United States has a inultiracial, multicultural heritage in which new immigrants continue to be highly acculturated. ${ }^{103}$ However, the response of some cultural pluralists, celebrating multiculturalism and envisionimg a peaceful coexistence annong different ethnic groups who are able to retain their cultures yet work together, is no less hyperbohic left unpacked. Multiracial commurnties that get along well do exist, and the majority of people of color continue to seek integration in conventional terms. Nonetheless, the significance of intergroup conflict and separatist sentiment deniands earnest reflection beyond the simplistic viewpoint that "a rambunctious America is a strong America."104

\section{A. Interethnic Group Conflict}

Immigration at massive levels . . creates societal problems.

In the United States, there has been gang warfare between Vietnamese and Hispanics in Denver.

-Richard D. Lamm \& Gary Iinhoff ${ }^{105}$

I think that we have to look at the fact that black people didn't just run outside and burn up their houses because they were angry. The Beverly Center was wrecked and that's in a white area. Korean businesses were targeted because that Korean woman shot and killed Latasha Harlans and she was convicted of the crime and she did not get one day in jail and we've got 25 percent of our black population behind bars doing exorbitant sentences for small crimes

101. Id. (quoting Patrick Buchanan).

102. Select Comm'N on Immigration \& Refugee Policy, supra note 2, at 417 (statement of Commissioner Alan K. Simpson, United States Senator).

103. See supra Part II; infra Appendix B.

104. Peters, supro note 76 , at B11.

105. Richard D. Lamm \& Gary Imhoff, The Immigration Time Bomb: The FRAGMENTING OF AMERICA 10-11 (1985). 
and we don't get justice. These are the reasons why people were attacked.

-Sister Souljah ${ }^{106}$

As politically volatile as it is, I wonder if we're failing [Korean American merchants] in Los Angeles.... the issue is if we go after skinheads or $K K K$ folks-people actually who are responsible for conduct of crime based on hate animosity -I wonder if we are negligent in not raising that issue [here against the black and Latino looters] because [Korean] folks who don't speak English, that's what they're feeling . . . . That is really the largest concern-racial hatred.

-Henry Der ${ }^{107}$

Conflicts involving immigrant groups attract banner headlines today. The aftermath of the first Rodney King verdict brought considerable attention to the conflict between the Korean American and African American communities in South Central Los Angeles. Many Korean American businesses were destroyed and one member of the community was killed. Such conflicts were not new to the popular media, but were magnified as images of Koreans arming themselves to protect their businesses against arson and looting aired throughout the nation.

In the Rodney King aftermath, diversity of opinion and reaction formed within the Korean American community. Some Koreans denounced the rioters, appearing to feel nothing but anger towards them. Others, while expressing sympathy for fellow Koreans who lost property and livelihoods, denounced the jury's verdict, vilified the racist judicial system, and supported the social and political motives of the protestors. ${ }^{108}$ In Korean American and other Asian American cominunity conversations and meetings, differences along lines of class, generation, and place of birth (native or foreign born) emerged. Some, but not all, older immigrant Koreans did not want to work or talk with African Americans. Younger Korean Americans often advocated building bridges between the two commumities. ${ }^{109}$

106. Listening to America with Bill Moyers (Public Affairs television broadcast, May 5, 1992).

107. AT\&T National Asian American Leadership Video Conference, New York, Chicago, Houston, San Francisco, and Los Angeles (June 24, 1992) (videotape on file with author).

108. For examples of Korean Americans' varying reactions to the Rodney King aftermath, see Garry Abrams, Out of Chaos, A New Voice, L.A. TIMEs, July 20, 1992, at E1; Steven A. Chin, Innocence Lost: L.A.'s Koreans Fight to Be Heard, S.F. ExAMINER, May 9, 1992, at A1; Susan Moffat, Splintered Society: U.S. Asians, L.A. Times, July 13, 1992, at A1; Tyson B. Park, Why Punish the Victims?, L.A. TIMEs, July 15, 1992, at B7; Eui-Young Yu, We Saw Our Dreams Burn For No Reason, S.F. ExAminer, May 24, 1992, at A13; Press Release from the Korean American Bar Association of Southern California (Apr. 30, 1992) (on file with author); Statement by Korean Americans for Racial Justice (May 9, 1992) (on file with author).

109. See Chin, supra note 108, at A5; Andrca Ford, Koreans, Blacks Try to Forge Alliance, L.A. TIMEs, Nov. 9, 1992, at B1; Stewart Kwoh et al., Finding Ways to Salve Intergroup Sore Points, L.A. TIMES, June 5, 1992, at B7. 
Among African Americans, an assortment of attitudes about Korean Americans emerged. Some blamed Korean Americans for taking busimess opportumities from African Americans, for gouging customers, and for removing money from the community, leaving hittle for local economic development. Some viewed Korean Americans as the tool of an economic system-a petit bourgeoisie-that had long oppressed African Americans. Others urged African Americans to work with Korean Americans in the development of the African American commumity. ${ }^{110}$

The tension between the Korean American and African American communities in South Central Los Angeles was not all racial. Much had to do with economic class divisions, as demonstrated by the similar destruction of Lationo and African American owned businesses. Understandably, niany pluralists and coalitionists argue that we must redesign our economic and social system to create nore opportunities because "[o]ne of the major factors contributnig to initer-minority tension is the conipetition for limited resources." 11 Thus, what appears to be a racial conflict may be actually a class dispute, or a mixture of racial and class eleinents.

Yet racial difference has played a role throughout the United States: in San Francisco housing project clashes, in conflicts between Vietnaniese and Latimos in Denver, Latinos and African Americans in Compton, and Pacific Islanders and Latinos in East Palo Alto. Violence between whites and people of color is still common, but tension and violence between groups of color is widespread as well. When we consider Korean American-African American conflict in South Central Los Angeles, African American-Jewish tension in Crown Heights, or LatinoAfrican American friction in Miami, much of the time we are faced squarely with the intersection of race and class. ${ }^{12}$ Competition for jobs, educational resources, and access to social programs often becomes defined in simplistic terms that ignore the multitude of causes.

110. For examples of African Americans' varying reactions to the Rodney King aftermath, see Ford, supra note 109, at B1; David Freed \& Charisse Jones, Blacks, Koreans Seek Conciliation. L.A. T1Mes, May 26, 1992, at A1; Patrick Lee, Not Business as Usual, L.A. Times, Aug. 21, 1992, at D1; Seth Mydans, Accused Looters Are Varied as Greatly as Things Stolen, N.Y. TIMES, May 7, 1992, at Al.

111. The Emerging New Majority: Black, Asian, Hispanic Relations in the '90s, AGENDA (Nat'1 Council of La Raza, Washington, D.C.), Fall 1992, at 10.

112. Similarly, when unemployed auto workers lash out at Japanese Americans as well as Japan, the motive is ostensibly economic, but racial overtones dominate. Certainly Japan-bashing begins because of the perception of Japanese auto market domination. See Ronald Takaki, Behind the Bashing of Japan. AsIAN WEEK, Feb. 14, 1992, at 2 (stating that imports of Japanese automobiles "have been denounced as an 'invasion" "). However, even if Germany's autos took a greater market share, it is unlikely that unemployed auto workers would beat German Americans because their race allows them to blend into white American culture and society. See TAKAKI, supra note 15 , at 13 . 
Recognizing the complexities will begin to help us formulate solutions to the tension and conflict.

\section{B. Separatism}

An African American attorney who is working with us to try to heal the wounds told a group of Asians just a few weeks ago that for her to promote pluralism in her community puts her on the lunatic fringe. Nationalism and ethnocentrism is definitely on the upswing in Los Angeles.

-Stewart Kwoh ${ }^{113}$

Do I really want to be integrated into a burning house?

White Americans find it as difficult as white people elsewhere do to divest themselves of the notion that they are in possession of some intrinsic value that black people need, or want. And this assumption-which, for example, makes the solution to the Negro problem depend on the speed with which Negroes accept and adopt white standards-is revealed in all kinds of striking ways, from Bobby Kennedy's assurance that a Negro can become President in forty years to the unfortunate tone of warm congratulation with which so many liberals address their Negro equals. It is the Negro, of course, who is presumed to have become equal -an achievement that not only proves the comforting fact that perseverance has no color but also overwhelmingly corroborates the white man's sense of his own value.

-James Baldwin ${ }^{114}$

The existence of linguistic and cultural separatism, about which Euro-immigrationists and cultural assimilationists complain, is undeniable. Latino barrios, Chinatowns, Little Indias, and Little Saigons have grown dramatically in number and size during the last twenty years. But before considering the factors that give rise to separatist communities and separatist sentiment, let us recognize that race and racism are at the root of many objections to these communities. When Euroimmigrationists and cultural assimilationists complain about the separatist threat to the umity and stability of the nation today, ${ }^{115}$ they are directing their charges against Asian and Latino immigration. Few, if any, of the charges question the presence of distinct coinmunities of Itahans, Poles, Hasidic Jews, and even Irish nationals in many U.S. cities. Racial difference appears to be the determinative factor. ${ }^{116}$

As part of thinking seriously about separatisin, we must begin by

113. AT\&T National Asian American Leadership Video Conference, supra note 107.

114. JAMES BALDWIN, THE FIRE NEXT TME 94-95 (Vintage International 1993) (1963).

115. See Select Comm'N ON Immigration \& Refugee Policy, supra note 2, at 411-12 (statement of Commissioner Alan K. Simpson, United States Senator).

116. See infra text accompanying note 123. 
considering what separatism is. There are at least two different types of separatism: 1) an ideological or political version; and 2) a sociological version.

The ideological or pohtical version can stem from anger over or disappointment in a system perceived to be weighted against certain classes or groups. For many, the anger provides an impetus to urge the community to engage in self-help and self-determination. Ideological separatism can result im physical separation, but it can also simply be a state of inind.

The sociological version arises from those who find comfort in a neighborhood with people of the saine cultural and linguistic backgrounds. Many people in these neighborhoods want to retain their cultural identity for themselves and for their children. A sense of safety night also be a factor for those who feel physically threatened by the dominant culture. The sociological version could also include those who find the ghetto the most affordable place to hive. ${ }^{117}$

Both political and sociological separatists might include some who judge others by race and wish to maintaim barriers along those lines. For example, certain people of color may distrust or be bitter about past treatment by whites and wish to avoid contact. Others may believe racial and ethmic stereotypes that reinforce avoidance and separatism.

In my experience, immigrants who reside or work in ethnic enclaves do so less out of ideological reasons than out of comfort or affordability, or as a result of housing and employment discrimination. I have the same sense regarding, but less experience in, the African American comniumity. For those African Americans who appear to have a choice, the ideology-comfort dichotomy is apparent. Thus, in Prince George's County, Maryland, a predominantly African American middle class suburb of Washington, D.C., some African American residents are there out of "a profound sense of disillusionment." In the words of one resident, "You want to call me a separatist, so be it. I think of myself as a pragmatist. Why should I beg some cracker to integrate me into his society when he doesn't want to? Why keep beating my head up against a wall, especially when I've been there."119 But others in the same neighborhood are less ideological: "I don't want to come home and always have niy guard up . . . . After I work eight hours or more a day . . . I don't want to eome home and work another eight."120 Another person

117. Keep in mind, however, that many residents of the ghetto are there because of housing discrimination rather than by choice. See, e.g., Douglas S. Massey and Nancy A. Denton, Trends in the Residential Segregation of Blacks, Hispanics, and Asians: 1970-1980, 52 AM. Soc. REV. 802, 823 (1987); Robert Pear, Bias Is Admitted by New York City in Public Housing, N.Y. TIMES, July 1, 1992, at A1.

118. Dent, supra note 5 , at 20.

119. Id. at 20-21 (quoting Radamase Cabrera).

120. Id. at 20 (quoting David S. Ball). 
agrees:

When I'm socializing with people who are not AfricanAmerican, I have to do a lot of explaining . . . . It's stressful because you know it's your responsibility to educate whites who have a smcere interest in understanding an issue. But it's more like work when you should just be socializing. If it's a black social setting, it's more like sharing ideas than educating. ${ }^{121}$

These comments illustrate the varied motivations for separatism epitomized by African Americans in Prince George's County. Some are there because of political disillusionment. Others are there out of comfort and seremity, preferring to socialize and interact with friends and family ratlier than shoulder the burden of educating non-African Americans about African American culture, life, and perspectives.

Similar types of separatist sentiment no doubt exist in certain white ethnic communities-for example, Jewish, Italian, and Irish-as well. Some may be race-based, but much derives from ethnicity. However, Asian or Latimo separatism receives mucli closer scrutiny because it involves immigrants of color who are easier to identify and target. Somehow ethnic separatism represented by Little Italys or Irish neighborhoods escapes criticism.

For Buchanan, Simpson, and FAIR, separatism by immigrants of color provides a reason for immigration restrictions. By their reasoning, the fewer immigrants (who today liappen to be mostly Asians and Latinos) tliat we allow in, the easier it is to limit separatism. This restrictionist approach does not address the understandable separatist reaction to exclusion and discrimination and the desire for ethnic community comfort. It also underestimates the strength of ideological and sociological separatism held by many immigrant groups of color who already live im the United States. The restrictionist response to separatism fails to recognize that much of the rationale behind separatism is not related to numbers. For many, separatist sentiment is a response to racism, exclusion, discrimination, and violence. Exclusionary laws and attacks on the Chimese in the late 1800s made the Chinese feel insecure, and Clinatowns correspondingly became more attractive. ${ }^{122}$ Exclusion leads to separatism, and dwindling numbers are only more likely to reinforce the trend.

The antiseparatist attack on immigration provides a convenient forum for attacks on separatism by people of color generally. Buchanan reveals his displeasure with African American separatism when he cites the lostile relations between white and African Americans and the latter group's failure "to assimilate into our society."123 Buchanan and other

121. Id. at 23 (quoting Edith Harvey).

122. See infra text accompanying notes 139-46.

123. See supra text accompanying note 101. 
assimilationists simply do not like separatism among groups of color, which they see as resulting from immigration: the greater the influx of immigrants, the greater the flight into ethnic enclaves. For the assimilationists, then, the problem only worsens because the very existence and growth of separate ethnic communities decreases imcentives to integrate and threatens the viability of hiberalism's solution to race relations. The end resnlt is increased pressure for restrictive immigration laws directed at Asians, Latinos, and Haitians. In the process, the underlying basis and rationale for the strong separatist sentiment among inmigrants of color, as well as African Americans and Native Americans, goes unaddressed, and society's ability to progress on issues of race relations is hainpered.

Although the flaws im Buchanan's extremist approach are easy to identify, separatism continues to trouble many who consider theinselves cnltural pluralists as well, especially those who supported integration as a fundainental coinponent of the struggle for civil rights and social justice. While not motivated by the racism of Buchanan, an integration-minded pluralist such as Todd Gitlin can relate to a Buchanan-like concern about "cultural balkanization":

Partly to resist homogenization and antisocial pressures, people identify with their separate tribes. Having learned not to have faith in central authorities, having grown skeptical of any reform politics that might build bridges, many altruists take refuge in their segregated commumities, competing for resources. The tribe-the ethnic or religious group, the profession, the affinity network-becomes the source of identity. But the tremendous vitality that results can becoine self-undermining. The sense of the common good is precarious. The commons is being paved over. ${ }^{124}$

Many cultural pluralists are anibivalent about separatisin. They may reject assimilationist-driven calls for immigration restrictions but still worry that separatism means rejecting integration. ${ }^{125}$ Make no mistake, cultural pluralists like Gitlin might not mind Chinatowns or Latino districts, but they are troubled when such coinmunities "pave over the coinmons" by declining to build bridges and participate in a larger national identity. When separatist ideology appears to reject a cominon national identity, the cultural pluralist experiences dissonance.

As a pluralist, I share this dissonance, but it makes me wonder if there is not a way of structuring or viewing our society within its current deinocratic and economic franiework in a way which is respectful of sep-

124. Todd Gitlin, Uncivil Society, S.F. Examiner, Apr. 19, 1992, Magazine at 13, 16.

125. See Harris, supra note 6, at B8 ("Dhanesh agrees . . that his fellow Indians need to become assimilated, become more involved in the wider community. 'Many of them, they're not doing their part of integrating.'") (quoting Dhanesh Bhindi). 
aratist sentiment. After all, it would not be the first time that dissonance, tension, or pressure led to something positive, including a better understanding of our society.

\section{Understanding Separatism}

Treatment of interethmic group conflict and separatism may affect the development of immigration policies, but these issues have relevance far beyond immigration concerns. They are related to questions of how we live as a society, how we are structured racially and ethnically, and how we perceive what it means to be an American. On one level, taking a closer look at separatism is important because of the dissonance it causes to both assimilatiomists and pluralists in the mamtenance of a common national identity, however that identity is constructed. On another level, understanding separatism is critical because that separatisin can and does contribute to hostility towards other groups, resulting in interethnic group conflict. This conflict can lead to the type of antiimmigrant sentiment epitomized by Buchanan, which in turn can reinforce separatist sentiment and interethnic conflict.

\section{a. Ideological Separatism}

Consider first those with strong ideologically-based separatist sentiment. The perpetuation of racism in the post-civil rights era has understandably led communities of color to focus on achieving political and economic viability. ${ }^{126} \mathrm{~A}$ theory based at least partially on race to explain the rise in separatist tendencies is not new. In his description of 1960s assimilation, sociologist Milton Gordon found racial exclusion to be an obstacle to full assimilation. In his paradigm, assimilation involves two distmct enterprises: 1) acculturation, or behavioral assimilation; and 2) structural assimilation, or social assimilation. ${ }^{127}$ Acculturation is the change of immigrant cultural patterns to those of the host society, while social or structural assimilation is the immigrants' large-scale entry into the general civic life of the receiving society, exemplified by social cliques, clubs, and institutions. ${ }^{128}$ Unlike acculturation, structural assimilation requires the dominant group to accept the immigrant group. Thus, mainstream acceptance is the decisive element in long-term adaptation.

Gordon concluded that, although considerable acculturation had occurred for most immigrants, structural assimilation was limited. ${ }^{129}$ This was particularly true for newer immigrants and racial minorities,

126. This largely represents disappointment and disillusionment with liberalism's promise of rights and formal equality.

127. Gordon, supra note 28 , at 279.

128. Id.

129. Id. at $280-81$. 
such as Italians, Poles, Mexicans, African Americans, and Puerto Ricans. ${ }^{130}$ Gordon attributed the retardation of structural assimilation to religious and racial differences between immigrants and the mainstream. ${ }^{131}$

There continue to be serious questions about wlietlier current power structures permit immigrants of color large-scale entry into the general civic or "prinary group" life of the receiving society. Separatist sentiment cannot simply be equated with a lack of preference for acculturation. Many communities of color have become separatist ouly after having sought acceptance in mainstream institutions and then liaving been rejected. After decades, even centuries, of unsuccessfully trying to break into the social and political structures of the country, inany concluded that they must take things into their own liands, forego reliance on the power structure, and look out for their own interests. ${ }^{132}$ Ideological separatists often encourage their communities to work, spend, and live in the community in a self-help political fashion. ${ }^{133}$ Their priority is taking care of themselves, since coalition work with otler coinmunities seeins to have generated few rewards. ${ }^{134}$

130. Id. at 281. As early as the 1930s, sociologists expressed concerns that because of conspicuous color or cultural heritage, immigrants were being targeted as outsiders. See, e.g., E.S. Bogardus, ANTI-FILIPINO RACE RIOTS 23 (Report to the Ingram Institute of Social Science, 1930).

131. Gordon, supra note 28 , at 281.

132. See infra Appendix A for a brief discussion of the Americanization efforts that targeted Native American children until the 1930s. In an effort to assimilate them, some children were isolated at schools for up to eight years and not permitted to see their families. Yet when these "Americanized" children were "sent out into a white world" they were rejected "because of their poverty and their race-regardless of their values." Ragsdale, supra note 80 , at 410 . Sadly, by then their reservations were foreign and unfamiliar to them as well. Id.

133. In the words of one Korean American leader: "We'll never be white people no matter how long we've lived here. We cannot afford to live in America scattered and isolated. Only through unity can our people protect our rights and pass on a great legacy to our children." KOREATOWN, Oct. 20, 1979, at 5 (statement by Han Mo Koo, President of the Korean Association of Southern California). See also Carl McClendon, Rodney King Redux: Symptoms of a Deeper Malady, ST. Petersburg Times, Mar. 21, 1993, at 1D ("The King beating comes on top a long list of incidents that have intensified blacks' ongoing internal debate over whether a society originally designed to exclude them can ever truly include them.").

Although the evolution of the hife and philosophy of Malcolm $\mathrm{X}$ symbolizes different things to different people, a Gallup poll showed that, to 84\% of African Americans, he represents African Americans helping one another. See Mark Whitaker, Malcolm X, NEwSWEEK, Nov. 16, 1992, at $66,72$.

134. For example, in Compton, California, where Latinos comprise $44 \%$ percent of the population, they hold only $9 \%$ of city jobs. MacNeil/Lehrer Newshour (WNET television broadcast, July 30, 1991) (statement by Jeffrey Kaye). Many Latinos felt that the predominantly African American city leaders were not responding to Latino needs, so one Latino decided to run for city council, saying:

There's a lot of frustration out in the community. We've asked our [predominantly Afriean American] city council to implement an affirmative action program. They have refused. We know what that means. I believe they see the writing on the wall. They see the demography changing very rapidly and do not want to share the power.

Id. (statement by Pedro Pallan). 
The ideological separatists do have a point. To Buchanan, FAIR, and their ilk, the proportionate increase in the number of people of color in the United States over the last twenty-five years, particularly among Latinos and Asian Americans, has led to more separatism. From the viewpoint of ideological separatists, however, the change has served only to highlight racial differences in the United States. As we have seen, although immigrants continue to acculturate and adopt distinctive American behavioral traits, many mainstreain institutions refuse to accept these immigrants of color. Certainly culture and language differences serve as a partial explanation for why today's immigrant groups continue to be excluded from certain social and economic institutions. ${ }^{135}$ But the race factor cannot be ignored. We read constantly about all white country clubs that continue to balk at adinitting members from other racial groups. ${ }^{136}$ Studies reveal glass ceilings that Asian Americans, Latinos, and African Americans encounter on the corporate ladder irrespective of acculturation and English-speaking ability. ${ }^{137}$ It is natural, then, for soine to turn away froin the mainstream in response to a rejection by the dominant power structure.

In addition to changing demographics, changing societal attitudes are also important to the foundation of ideological separatism. The patchwork of ethnic groups in the United States has grown even inore diverse with increased imınigration, contributing to greater diversity of opinion even within Latino and Asian American coinmunities. Meanwhile, two new generations have emerged-one whose beliefs and attitudes were shaped during the civil rights movement, and a subsequent one whose expectations were influenced by that niovement. The earlier generation guided the civil rights moveinent. The latter generation has developed its own interpretation of what has occurred over the last thirty years and is defining new civil rights strategies for the struggles ahead. Consciousness about civil and human rights has increased over the last thirty years, and in institutional arenas, tolerance of racism has decreased. This is not to deny that retrenchment on nnany of these fronts has occurred. A backlash against affirmative action and forced busing, as

135. See, e.g., Jaime Diaz, Shoal Creek Decision Puts Golf on a New Course, N.Y. T1MES, Jan. 14, 1991, at C6 (discussing the exclusion of a Jewish businessman from a Kansas City country club, former Vice President Dan Quayle's patronage of Cypress Point (an exclusive club on the Monterey Peninsula that refused to conform to pro golf's antidiscrimination policy), and other clubs which continue to exclude people of color); Lawrence O. Graham, Invisible Man, N.Y. MAG., Aug. 17, 1992, at 26, 26-34 (discussing his experiences with discrimination at an exclusive country club in Connecticut).

136. See Diaz, supra note 135 , at $\mathrm{C6}$.

137. See Chinese for Affirmative Action, The Broken Ladder '89: Asian americans IN City Government (1989); Veronica Byrd, The Struggle for Minority Managers, N.Y. TIMES, Mar. 7, 1993, § 3, at 27; Shawn Hubler \& Stuart Silverstein, Schooling Doesn't Close Minority Earning Gap, L.A. TIMES, Jan. 10, 1993, at A1; Ruben Navarrette, Jr., Education's Broken Promise to Minorities, L.A. TIMES, Feb. 14, 1993, at MI. 
epitomized by the Bakke case in the 1970s and by the move to dismantle preferential programs in the 1980s, is also unmistakable. ${ }^{138}$ The combination of progress and retrenchment has fostered an environment ripe for ideological separatism.

\section{b. Sociological Separatism}

For those who seek separate ethmic and racial commumities out of comfort, the choice is often a simple matter of familiarity with language, culture, and behavior. If there were more mainstream social and institutional acceptance of various ethnic groups, there would be less need for nonideological separatists to seek enclaves out of comfort. The historical development of Chinatowns is a useful model for understanding this sociological separatist sentiment, as well as ideological separatist sentiment.

Ineligible for citizenship, and targeted by harsh discrimination and an array of repressive state and local laws, the Chmese found themselves segregated and excluded from white mainstream society. Many laborers resettled in urban Chinatowns. Some needed jobs as gold mining waned and the transcontinental railroad was completed in 1869 , but others had spent their lives working the land. Often they knew little of urban life, and even feared it, but were forced to move nonetheless. ${ }^{139}$ An 1879 California law (soon after declared unconstitutional) required imcorporated towns and cities to remove Chinese residents from city limits. ${ }^{140}$ In 1885, a Tucson petition urged that Chinese be required to live in a Chinatown. ${ }^{141}$ Landlords and realtors refused to rent and sell to Chinese outside the Chinatown, and whites threatened violence against those who passed certain boundaries. ${ }^{142}$

The white mainstream and the Chinese understood this forced migration to Chinatowns in two quite contrasting ways. For white mainstream citizens, Chinatowns helped resolve the dilemma of simultaneously needing the Chinese, or some foreigu group like them, for domestic

138. See, e.g., City of Richmond v. J. A. Croson Co., 488 U.S. 469 (1989) (striking down a city program that set aside subcontracts for minority-owned businesses without a showing of past discrimination); Wygant v. Jackson Bd. of Educ., 476 U.S. 267 (1986) (ruling a collective bargaining agreement unconstitutional because it provided that in the event of layoffs, the percentage of laid-off minority teachers could not exceed the percentage of minority teachers currently employed); Susan B. Garland, The Civil Rights Champion Trying to Mend Bush's Fences, Bus. WEEK, Dec. 31, 1990, at 63 (discussing President Bush's veto of a bill that would have helped victims of job discrimination win lawsuits, and the Department of Education's proposal to restrict scholarships reserved for minority students); Frank Trippett, A Solid Yes to Affirmative Action, T1ME, July 14, 1986, at 22, 22 (discussing the Supreme Court's rejection of the Reagan Administration's claims that only actual victims of discrimination deserve affirmative action).

139. See, eg., Rose Hum Lee, The Chinese in the United States of America 13 (1960) (describing anti-Chinese campaign).

140. Sucheng Chan, Asian Americans: An Interpretive History 56 (1991).

141. See John R. Wunder, Law and the Chinese on the Southwest Frontier, 1850s-1902, 2 W. LEGAL HIST. 139, 141 (1989).

142. See Chan, supra note 140 , at 57 . 
and service jobs, and fearing their unknown "Oriental" powers. Chinatowns meant whites could keep an eye on the Chinese-check their wanderings and aspirations, their capacity to "imfiltrate" white society, and their economy and politics-yet remam at arm's length.

For the Chinese, Chinatowns provided a measure of much-needed security and comfort. The Chinese frequently suffered mob attacks during the anti-Chinese furor of the late-nineteentli and early-twentieth centuries. ${ }^{143}$ In the relative safety and comfort of their own enclaves, they created formal associations based on geographic origin and family clans that helped meet their economic, social, religious, educational, and political needs. ${ }^{144}$ These networks were particularly important to the men, who needed a substitute for the traditional families they were denied. ${ }^{145}$ With the advent of exclusion laws, the Chinese population dropped, ${ }^{146}$ inaking the need for Chinatowns even more compelling. ${ }^{147}$

Other minority groups, such as Koreans, Japanese, and Vietnamese, have followed the same pattern as the Chinese. The pattern cuts across race lines as well. Jews, Poles, Irish, and Italians are examples of white immigrants who have establislied their own enclaves.

The notion that one might prefer segregation because it provides a more comfortable environment ${ }^{148}$ can be unsettling. We may understand the reasons behind separatist sentiment, but still experience dissonance. If whites say they want to live among themselves exclusively, or even in a predominantly wlite neighborliood, we construe such sentiment as segregation and racism. Is the analogous preference among people of color different? Is it more justifiable? Perhaps it is. For example, if an exclusively Japanese American California community, including elders interned during World War II, chooses to live in a segregated neighborlood because of bitterness over internment and the safety and comfort of being around other Japanese Americans, we might find such a reaction understandable. If we can empathize with previously-interned Japanese Americans who want to live together, then we might begin to understand a similar sentimient among other groups of color.

143. For a detailed account of such mob attacks, see SHIH-SHAN H. TSAI, THE CHINESE EXPERIENCE IN AMERICA 67-72 (1986).

144. LEE, supra note 139, at 142-52; see also HARRY H.L. KITANo \& ROGER DANIELS, AsIAN AMERICANS: EMERGING MINORITIES 25-26 (1988).

145. See Victor G. Nee \& Brett de Bary NeE, Longtime CaliforN' 13-29 (1972). The overinclusive enforcement of an 1875 law barring the entry of Chinese prostitutes, the intent to exclude women and men under the 1882 Chinese Exclusion law, and antimiscegenation laws in states such as California and Oregon made it very difficult for Chinese male workers to marry and form families. HiNG, supra note 11 , at 45 .

146. TSAI, supra note 143, at 72-73.

147. One irony of separatist movements is that, while ethnic ghettos havc for some time been imposed on people of color, when they themselves advocate separatism, those powerful forces that created and perpetuated segregation become particularly upset.

148. See generally Dent, supra note 5 and accompanying text. 


\section{Racism, Lack of Control, Identity, and Diversity}

Advocates of conventional cultural pluralism disquieted by separatist ideology must not ignore the realities of past and present racial discrimination. It is quite appealing for progressives to support the retention of culture by people of color, respect for differences by the power structure, and the sharing of power and equal access to institutions, in which case separatism might not be necessary. The problem is that things have not worked out that way. First, immigrants of color have yet to be fully incorporated into the social and political structures of our society. Many immigrants and groups of color think inclusion in the power structures of Wall Street, corporate boardrooins, elite educational institutions, and certain social institutions is not a realistic possibility. Certainly some people are quite liappy in their communities and do not desire acceptance in inainstream institutions. Within a broad paradigm of cultural pluralism, this presents no fundamental problein. ${ }^{149}$ For those who do desire mclusion within the inainstream society, however, exclusion is grievous and harmful. Exclusion froin the mainstream power structure is most obvious because it encompasses the inajor social, political, and economic institutions of the country. At the local level, exclusion is no less harmful; exclusion from neighborhood, school, and formal social groups can mean all the difference to an individual or commuinty trying to be part of that social group. ${ }^{150}$

Separatist sentiment lias everything to do with race discrimination. Today's inmigrants face hostilities similar to tlose faced by their white predecessors. The biggest difference between today's Asian, Latino, and Haitian immigrants and Irish, Italian, and Southern and Eastern European immigrants of decades past is race. Certainly, all of these groups faced liostilities, discrimination, and even violence, but eventually the Irisli and Europeans became part of the mamstream. ${ }^{151}$ Eventually, European immigrants coalesced for identity purposes into the new monolithic European American category. By contrast, for "racial minorities, there was not even the pretense of an invitation" to join the power structure. ${ }^{152}$ While Jews are still excluded from certain levels of business and social circles, they have achieved soine success in entering the professional structure. ${ }^{153}$ But new immigrants of color are generally ostracized from business, government, and social circles. The lack of social accept-

149. See infra Part V.B.

150. This explanation of exclusion underscores the importance of separate communities because within these communities, people of color can find acceptancc at the local level: in neighborhood, school, community, and formal social groups. Secure in their identities, they can then enter the mainstream with greater confidence.

151. Replicating the animosities that they had faced on the Atlantic Coast, the Irish led much of the anti-Chinese sentiment on the Pacific Coast in the 1800s. See HiNG, supra note 11, at 21.

152. Gordon, supra note 28 , at 282-83.

153. Interview with Allan Brotsky, Professor at Golden Gate University School of Law, in San 
ance, in particular, plagues new immigrants of color and contributes to separatism.

A desire for self-determination is particularly understandable given the continumg economic struggles of many within communities of color. ${ }^{154}$ It is easy to assume that this does not apply to all people of color, particularly Asian Americans. A popular misconception is that Asian Americans (as well as professionals of color) do not experience the effects of discrimination and racial and economic stratification. On the contrary, the few professionals of color who are successful in mainstream society often bear the burden of having white society treat them as ambassadors or representatives of their entire race. Thus, even in professional circles, the expectations for people of color are often quite different from those of European ancestry.

White Americans contmue to control the principal economic, social, and political institutions of the country. We continue to read about the all-whitc country clubs to which pohtical and business leaders and judges belong. ${ }^{155}$ It does not take long for communities of color to become skeptical about the willingness of a powcr structure dominated by whites to permit full assimilation. The fact that inany poor whites are also excluded does not diminish the doubts. Racism permeates lower socioeconomic classes just as surely as it does highcr ones. If racisin persists, more people of color will react in separatist ways. Certainly many whites do not feel in control of the power structure, but people of color see that even outside the board rooms and the political elite, whites are primarily in control of the clubs, the leagues, and other social organizations. Moreover, people of color who experience the exclusion froin those institutions see whites as responsible for the exclusion. Although many whites are not part of the power structure, it is whites who have institutional control in most instances. While people of color can be found in positions of control in some mainstream institutions, these cases are rare.

Since people of color generally lack control over mainstream institutions, they ought to be allowed to maintain an environment where they can function autonomously. If white Americans have control over most mainstream structures, why shouldn't people of color be allowed to seek alternative structures, even separatist ones, to control at least part of

Francisco, Cal. (Mar. 18, 1993). In response to exclusion, Jewish men in the past formed their own clubs, yet membership was not limited to Jews. Id.

154. I understand that many whites struggle economically and sense little control over the power structure. Theirs is a class fight, as is true for many people of color. But because of higher percentages of poverty in communities of color and exclusion from social institutions and the power structure irrespective of class, communities of color, particularly separatists within those communities, tend to view the problems in terms of racc.

155. See, eg., Diaz, supra note 135 , at $\mathrm{C} 6$ (discussing exclusive country clubs and their discriminatory practices); Graham, supra note 135, at 26-34 (discussing an exclusive country club in Connecticut). 
their world and advance and provide for their families? To be sure, the anger that impels a community to self-help can lead to more destructive speech and behavior that is based strictly on race or ethnicity, such as anti-Asian sentiment or anti-Sernitism. At this point, separatism becomes indefensible. However, apart from this, a philosophy of separatisin that is based on self-help should be fostered and defended.

Respect for separatisin also flows from understanding that for many people of color, separatism plays a critical role in their identity. Many people of color are isolated or have no sense of identity in the mainstreain-for exainple, at work, at school, or in social settings. ${ }^{156}$ They need their ethnic commumity to develop a sense of self. Their communities inay provide a better chance to learn about and develop respect for their own race and culture. Like the family, the ethnic commurrity often supports an individual's enotional, social, and pohtical development, when that person would otherwise flounder in the inainstreain. ${ }^{157}$ Certainly this is not true for all people of color, but for many the ethnic community inakes a huge positive difference. At the very least, the availability of the option is crucial.

Understanding separatisin also ineans understanding that each cominunity is coinprised of meinbers with diverse points of view about separatism, plurahism, coalition building, race, and assimilation. Some who are not separatists inay downplay or cast aside their race and submerge theinselves in the mainstreain culture and its promise of a true ineritocracy. Some may form coalitions with other groups of color. Still others reject their own racial commumity's mainstreain cnlture as thor-

156. Mainstream media are of little help because they portray and perpetuate negative stereotypes. Consider common depictions of Asian Americans.

Reporters are not alone in stereotyping Asian Americans and Asian immigrants. Bespectacled math whizzes and buck-toothed businessmen are standard characters on television and in the movies. Often these figures are depicted as fools whose conversation is filled with fortune cookie clichés. Asian women frequently appear as exotic sex objects rather than as multidimensional characters. Asian communities are "filled with thoroughly ruthless ganglords, evil drug rings, secret taverns, and hidden lairs behind neon lights."

HiNG, supra note 11, at 11-12 (footnotes omitted). The media do occasionally portray people of color more positively. When M.I.T. admitted several Mexican American students from a high school in Texas last year, one newspaper profiled them in a highly favorable light. Mark McDonaid, Making the Grade: Five Students from El Paso Are Learning What It Takes to Survive Fabled MIT, Dallas MoRning News, Jan. 2, 1993, at 1C.

157. Over the years I have had countless students of color who find law school unbearable until they work or volunteer in a community law office and help people from the same racial background. The community provides these students with a sense of purpose and identity that positively affects their attitude about law school. In fact, this was my experience when I attended law school in the early 1970s and worked at the Chinatown office of the San Francisco Neighborhood Legal Assistance Foundation. 
oughly as they reject white mainstream culture. ${ }^{158}$

Understanding separatism means recognizing that immigrant adaptation should not rest solely on the shoulders of the immigrants. In order to elicit some commitment from separatist communities to participate in a core or central culture, viewing immigrant adaptation as a dual responsibility is necessary. Those in control of the power structure and mainstream social institutions have a duty as well.

Soine may look for a simple, idealistic form of cultural pluralism that preserves groups' ethnic identities but also advocates participation in a common pohitical, social, and economic identity. The reality of the diversity of opimions within communities of color is likely to frustrate such idealists. Perhaps by understanding the thinking behind these varied views, we can begin to accept a form of cultural pluralism that recognizes the vahidity of even the most ideological separatist sentiment.

\section{V}

\section{A New Approach to Cultural Pluralism: DeVELOPING THE CORE}

Forty-two [San Francisco] Bay Area cities and towns now have nonwhite and Hispanic communities that form at least a third of their populations-a dramatic increase over the 22 recorded in 1980.

"What we are seeing here is the appearance of a new kind of American metropolis."

[The Bay Area] is not an urban region where immigrants are concentrated exclusively in aging inner cities.

It is not a region that has grown more desperate as it has grown less white.

And it is not a region where perfect English, European descent and an American birthplace sum up the chief formula for success.

"The familiar image of distressed, nonwhite, declining core

158. Prominent African Americans such as Jesse Jackson and Magic Johnson are no more effective than President Bush in reaching alienated urban black youtlis ....

...

Houston Baker, director of the Center for the Study of Black Literature and Culture at the University of Pennsylvania . . . was surprised and diseouraged by the teen-agers' rejection of black culture.

"Even when presented by stunning role models like Magic Johnson, they don't want to hear it."

Young Blacks Reject Black, White Mainstream Culture, S.F. ExAMINER, May 27, 1992, at A2 (quoting Houston Baker); see also Lyle V. Harris, Reaching the Hip-Hop Generation, ATLANTA J.CoNST., Mar. 7, 1993, at C1, C4 ("Successful blacks who might otherwise be considered good role models may be rejected because they seem foreign to the hard-core street culture from which hip hop springs.") 
cities surrounded by white suburbs simply doesn't apply to the Bay Area."

-Frank Viviano ${ }^{159}$

Any time young [African Americans] harbor an inferiority complex about themselves, it demonstrates race relations in [San Francisco] are not the best, and we have a long way to go.

-Amos Brown ${ }^{160}$

Cultural pluralisn is alive in the United States. Its advocates tire of the assinilationist stridency which envisions a narrow, anachronistic, and European American notion of what it means to be an American. At the moment, a nodified pluralism controls an immigration pohicy which, except for certam restrictive refugee pohicies, is more open than ever. Asians and Latmos dominate the predominantly family-based immigration systen1. Recently available diversity visa programs are designed to permit Africans to use them, and niany Latios and some Haitians and Cubans were granted amnesty under a 1986 law. ${ }^{161}$ The government is no longer engaged im official Americanization progranis aimed at supplanting immigrants' cultures. ${ }^{162}$

While cultural pluralisin is alive, it may not be well. Assimilationists have tired of what they view as a fanciful, doctrinaire vision of a nulticultural society. After experiencinig sonie progress im the areas of social acceptance, political influence, and economic development, ideological segments of ethnic and racial minorities in the United States have noved away from the dream of a cultural plurality towards separatism. ${ }^{163}$ For most of these separatists, the search is for a society in which they are valued and have a level of control over the institutions that influence their lives.

If some nianifestations of separatism are regarded as evil-such as the rejection of a comnion core culture or set of values-then the biggest blame should be placed at the feet of those who have excluded people of color front the power structure. Thus, the anti-inimigrant statenients of Buchanan and FAIR are not only misguided in their avoidance of dealing with the tension created by mterethnic violence or separatism, but

159. Frank Viviano, A Rich Ethnic Mix in the Suburbs, S.F. Chron., May 11, 1991, at A1, A15 (quoting Richard LeGates, Director of Urban Studies at San Francisco State University).

160. Donna Birch, Forum Tackles Race Relations in San Francisco, S.F. ExAMINER, July 24, 1992, at A7 (quoting Amos Brown, Pastor of the Third Baptist Church in San Francisco).

161. See infra Appendix A.

162. Cf. id. (discussing prior Americanization programs aimed at Mexicans and Native Americans).

163. Critical race theorists, for example, have detailed their disappointment and disillusionment with liberalism. See Derrick Bell, AND WE ARE Not Saved: The Elusive Quest for Racial Justice (1987); Patricia J. Williams, The Alchemy of Race and Rights (1991); Richard Delgado, The Ethereal Scholar: Does Critical Legal Studies Have What Minorities Want?, 22 Harv. C.R.-C.L. L. Rev. 301 (1987); Mari J. Matsuda, Looking to the Bottom: Critical Legal Studies and Reparations, 22 HARV. C.R.-C.L. L. REV. 323 (1987). 
also counterproductive to the adaptation process of the very immigrants that concern them. Buchanan and FAIR's Euro-conformity doctrine is irrelevant to an already multiracial nation grappling with separatism and ethnic conflict. ${ }^{164}$ Furthermore, their divisive and spiteful attack on immigration may discourage immigrants from striving to acculturate. Urging the revision of immigration laws to allow only European immigrants or Englislı speakers is telling over eighty percent of our immigrants that we do not like them; that there is something about their race and language that is offensive; that because of their race, language, and culture they do not belong in this country.

We all sliare to varying extents the blame for a culture that gives rise to protests epitomized by the uprising in South Central Los Angeles. Every time we engage in even subtle racism or the fostering of stereotypes, we perpetuate that culture. As much as each of us shares the blame, each of us also has the opportunity to be part of the solution. Every time we reach out to others whom we have been conditioned to distrust, fear, or subordinate because of race or class, we begin to chip away at the wicked culture that gives rise to irrational hatred, animosity, and violence. ${ }^{165}$

164. See GATES, supra note 66 , at xvi ("[T] $]$ he world we live in is multicultural already. Mixing and hybridity are the rule, not the exception.")

165. On more than one occasion, white acquaintances, friends, and students have confided that they grew up being taught a "we/they" perspective where people of color are "they" and are potentially dangerous. It is difficult to rid oneself of those feelings. Thus, it comes as little surprise to learn of the distinctive fear that many non-African Americans have of African American males encountered on the street. See, e.g., EliJAH ANDERSON, STREeTw1Se 164 (1990). Similarly, some people claim to be "wary of black men and generally nonchalant with Latinos." Jack Miles, Blacks vs. Browns, ATLANTIC MoNTHLY, Oct. 1992, at 41, 58. In a Los Angeles Times poll conducted before and after the verdict in the first case against the police who beat Rodney King, only a minority of whites said they would favor living in a neighborhood where half of their neighbors were either Asian, African American or Latino. Amy Wallace, Riots Changed Few Attitudes, Poll Finds, L.A. Times, Sept. 3, 1992, at B1, B8.

Furthermore, when an African American corporate lawyer took a leave of absence from his $\$ 105,000$-a-year job to become a $\$ 7$-an-hour busboy at a Connecticut country club to get a sense of its membership's attitudes towards race, the culture of racist stereotyping became chillingly clear. In one instance, he served the father of a former classmate whom he had met on several occasions. "I served him three times at his table, and he looked right at me . . . and did not recognize me. I was just soineone to serve them, nothing more than that. And that was when I realized I was really invisible here." Steven Radwell, Invisible Man Visits a Country Club, S.F. Examiner, Aug. 23, 1992, at B8; see also Graham, supre note 135, at 26-34. While one ean argue that any busboy could be treated as invisible, I cannot help but think that this African American's skin color contributed greatly to his treatment while in busboy uniform, particularly in light of his previous meetings with the white man he served. Studies confirm this correlation between race and disparate treatment suffered by well-dressed African Americans at the hands of landlords, retail merchants, and automobile salespersons. See, e.g., Ian Ayres, Fair Driving: Gender and Race Discrimination in Retail Car Negotiations, 104 HARv. L. REv. 817 (1991).

Yet consider these words from a white author illustrating the opportunities for breaking down the distrust:

As I walk down the street, mumbling to myself, I see an elderly black woman, toting two heavy bags. She's finished a day's work at the white lady's house. She is weary, frowning. 


\section{A. Defining America}

\section{Each generation of Americans must define what it means to be an American.

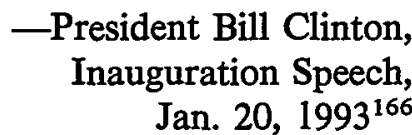

Irrespective of labels, ${ }^{167}$ we need new ways of looking at what it means to be an American. After surveying scores of individuals on the meaning of becoming an American, it is clear to ine that the concept signifies different things to different people. Recognition of these differences helps develop a respect for other cultures and sets the groundwork for a workable multiracial society. This groundwork can help us counter the human tendency to divide and distinguish in binary terms of superiority and inferiority. We must overcome that tendency in order to meet the prerequisite of respect for diverse views in a new vision of plurahism. Neither Euro-conformity nor conventional pluralisin adequately describes what is happening. A multiracial process that accommodates separatisin for those people of color who choose it deinands new ways of

I say, as a matter of course, "How's it goin'?" She looks up. Her face brightens. "Fine. And you?"

Three young black kids are swaggering along. As they come toward me, I say, "How's it goin'?" The tall one in the middle is startled. "Fine. And you?"

A presence was acknowledged. That was all.

I am not suggesting a twilight stroll through the walkways of a public housing project. The danger is not so much black hostility as a stray bullet fired by one black kid at another. What I am suggesting is something else: Affirmative Civility.

Studs Terkel, Race: How Blacks and Whites Think and Feel About the American OBSESSION 17-18 (1992). As David Mura states:

To dig out the roots of racial resentment, Americans must come to terms with their subjective vision of race. If someone of another color gets a job you're applying for, is your resentment more than if a person of your own color won the job? When you hcar the word American, whose face flashes before your mind?

David Mura, Bashed in the U.S.A., N.Y. TIMES, Apr. 29, 1992, at A17.

166. President Bill Clinton, Inaugural Address (Jan. 20, 1993), in WASH. PosT, Jan. 21, 1993, at A26.

167. Henry Louis Gates sets up the debate as follows:

The Conservative (these are caricatures, and I apologize), extolling the achievement of something narrativized under the rubric "Western civilization," says: Nobody does it better. We Liberal Reformists say: Do unto others as you would have them do unto you; and-hope for the best. The Left says: Let's do unto you what you did unto Others; and then see how you like that.

For them, what's distasteful about the ideology of pluralism is that it disguises real power relations; that it leaves the concept of hegemony unnamed; that it is a defeat that masquerades as victory; that it is an idyllic picture of coexistence that supervenes upon harsh realities. Pluralism, for them, fails to be adequately emancipatory; it leaves oppressive structures intact.

There are at least two things to notice here. First, if the hard left is correct, then the hard right has nothing to worry about from the multicultural initiative. Second, the hard left distinguishes itself from the liberal pluralist position in its frank partisanship; it subsists on a division between hegemons and hegemonized, center and margin, oppressor and oppressed, and makes no bones about which side it's on.

GATES, supra note 66 , at 176-77. 
thinking. Under a new version of pluralism, separatists would be welcomed when their separatism was based on self-help, self-determination, and comfort, rather than destructive racial or ethric sentiments aimed at other groups. Concepts of what it means to be an American must mclude the diversity of new generations of Americans-foreign-born, native-born, white, and of color-and be cognizant of the tension that accompamies diversity. Catch phrases, like melting pot or salad bowl, are not useful descriptions of our complex society.

Clinging to a Euro-conformity paradigm of what constitutes an American is simultaneously fruitless and dangerous. When culture and race assimilationists advocate their positions, they ignore the demographic realities of the nation. In 1990 , about $25 \%$ of the nation was comprised of people of color: $12.1 \%$ African American; 9\% Latino; 2.9\% Asian American; and $0.8 \%$ Native American. ${ }^{168}$ According to one federal study, by the year 2000, African Americans and Latinos will constitute $47 \%$ of the population. ${ }^{169}$ The Census Bureau predicts that the rate of growth for white Americans between 1992 and 2050 will be 29.4\%. The growth rate among groups of color will be much greater: 93.8\% African American; 237.5\% Latino; $412.5 \%$ Asian and Pacific Islander; $109.1 \%$ Native American. ${ }^{170}$ Left to market forces, immigrants are indeed Americanized, picking up habits, cultural traits, values, interests, and langnages of the dominant group. However, market forces also have worked in a manner which has resulted in an American culture that is constantly changing, and which constantly redefines what an American is. As immigrants become more "American" due to these market forces, their native cultural traits also influence existing social norms. Thus, just as the process of Americanization has evolved from one of Anglo-conformity to Euro-conformity, it is evolving into a multicultural-conformity that requires us to look at our society and culture with a broader perspective. This change has been gradual because of the strength and ubiquity of the doininant culture. Yet change has occurred, and the futility of defining what an American is in purely Euro-centric terms should be apparent.

Just as the advocacy of white-only immigration is counterproductive to the adaptation process of nonwhite immigrants, the continued definition of American in Euro-centric terms is fraught with danger. Indeed, the rhetoric of Buchanan and Duke suggests that this is their purpose. ${ }^{171}$ Expressions of Euro-Americanization help racists confirm their views of

168. See supra text accompanying notes 8-11.

169. See William Douglas, Scientist-Educator to Head New York City Tech College, NEwSDAY, Jan. 11, 1990, at 21.

170. See Robert Pear, New Look at the U.S. in 2050: Bigger, Older and Less White, N.Y. T1MES, Dec. 4, 1992, at A1, A10.

171. For a discussion of Buchanan and Duke's racist tone, see supra Parts I.A and II.A. 
racial superiority over people of color. White supremacists feed on this type of sentiment and manipulate advocacy for Euro-conformity to their benefit by finding new recruits initially attracted to the more benign notion of strengthening the nation through unity. The hazards of such a process are clear. Resentment of immigrants is engendered, scapegoating of people of color becomes easier, racial and ethnic epithets remain commonplace, and hate violence ensues.

Iminigrants do acculturate. Assimilation is a fluid and evolving process rather than a static one. Furthermore, immigrants' presence also influences the ongoing evolution of American culture. As a result, the definition of what an American is must be expanded. The concept must be one of addition rather than oinission. It must embrace differences rather than attack them. It must respect diversity rather than disregard it. It must appeal to a sense of umity that incorporates multiculturahism rather than utilize the pretext of Euro-centric unity that is simply a mask for ostracizing other cultures.

Thus, the new definition of "what it means to be an American," which our new President has challenged us to provide, ${ }^{172}$ is one of inclusion rather than exclusion. It respects the history, the traditions, the culture, the literature, the values, the language, and the music of Native Americans, African Americans, Latinos, Asian Americans, Pacific Islanders, and others as those cultural qualities have distinctly evolved within our borders. This modern vision recognizes that the Navajo's respect for the earth and its natural resources is an American value; that the African American-led civil rights movement of the 1960s represents a powerful moment in our American history; that the continuing nightmares of torture and heartache endured by Cambodian refugees is a component of the American psyche; that the folklore and labor of Mexican farmworkers is an American experience. It recognizes that the American experience is broad and diverse. In short, it recognizes that being an American can mean different things to different people, but simultaneously recognizes that each experience contributes to the national story and each achievement leads the nation forward.

\section{B. Improving Race Relations and Multicultural Awareness}

Today, a jury representing the diversity of our city found the truth [in convicting Sgt. Stacey Koon and Officer Lawrence Powell in the beating of Rodney King]. Now, Los Angeles must move on. We must move ahead. Today's verdict, by itself, will not create more jobs, or better schools or bridge our differences.

-Tom Bradley ${ }^{173}$

172. See supra note 166 and accompanying text.

173. Steven A. Chin et al., All Calm After Verdict, S.F. Examiner, Apr. 18, 1993, at A1, A8 (quoting Tom Bradley, Mayor of Los Angeles). 
It is clear that we need a new commitment to race relations and multiculturalism. Less than twenty years ago, there was little in the way of an environmental movement in the United States. Yet with leadership, planning, commitment, and persistence, we have become an environmentally-conscious society. School children are taught about the environment. We devote local government efforts to recycling and reducing waste. Water conservation is a high priority in some states. The federal Environmental Protection Agency has state counterparts with staffs devoted to environmental issues. An entire lexiconrecyching, pollution, air quality, biodegradable, greenhouse effect, global warming, ozone depletion, rain forest-has developed during this time. ${ }^{174}$ Many of us do not act without thinking about the possible impact on the environment.

The same kind of cominitment is needed for race relations and multiculturahism. ${ }^{175}$ We need to promote constant awareness of interethnic group relations, elimination of conscious and unconscious racisin, ${ }^{176}$ and social acceptance of people of color. We must reach a new level of consciousness, strive to develop a new, inclusive vocabulary, explore new ways of being American, and recognize the variety of racial and ethnic issues that face our society. We must urge one another to judge people by the "content of their character" rather than by skin color. ${ }^{177}$ Although we are not all environmentalists, and we are comınitted to the

174. Similarly, recent commitments of the Clinton administration to overhaul the health-care system have been labelled "ambitious" and are expected to represent "a vast change in the way medical care is organized and delivered." Robert Pear, Clinton Health-Care Planners Are Facing Delicate Decisions, N.Y. T1MEs, Mar. 23, 1993, at A1. A special lexicon in this regard has developed as well: employer mandate, fee for service, global budget, health insurance purchasing cooperative, health maintenance organization, managed care, managed competition, medieaid, medicare, tax cap. Id. at $\mathbf{A} 9$.

175. I realize that there is an enormous difference between how people feel about newspapers and bottles versus race relations. Interaction and dealings with real people are obviously far more complex. For many, less emotion and volatility attach to aluminum cans and recycled paper than to a street encounter with someone of a different race, language, or ethnic background. The point, however, is that society has invested a great deal of time and effort in the environmental movement to the betterment of our environment. While racial issues are more personal and even more difficult for many people, we have yet to invest the same commitment to race relations.

176. Professor Charles Lawrence points out that

Americans share a common historical and cultural heritage in which racism has played and still plays a dominant role. Because of this shared experience, we also inevitably share many ideas, attitudes, and beliefs that attach significance to an individual's race and induce negative feelings and opinions about nonwhites. To the extent that this cultural belief system has infiuenced all of us, we are all racists. At the same time, most of us are unaware of our racism.

Charles R. Lawrence III, The Id, The Ego, and Equal Protection: Reckoning With Unconscious Racism, 39 STAN. L. REv. 317, 322 (1987). His reminder also enables us to see that even the cultural assimilationist perspective may very well be racial at its core. See supra text accompanying notes 40-46.

177. This phrase comes from Martin Luther King's famous "I Have a Dream" speech: "I have a dream my four little children will one day live in a nation where they will not be judged by the color of their skin but by content of their character. I have a dream todayl" A TESTAMENr of 
environment in different degrees, even that level of awareness in a new commitment to interracial relationships would be much better than what we have today, when interracial dialogue is minimal and positive discussions even within communities about other commumities receive low priority.

A viable multiethnic, multiracial society that recognizes a need for separatism in certain sectors, yet simultaneously urges some form of common American political identity, is not impossible or inconsistent. Diversity of opinion runs deep. Even annong separatists, significant differences arise concerning the degree of desired separatisin, often based on class, experience, education, and economic background. For example, some may seek more active coalition building, while others may reject it. Those within a particular ethmic commumity, as well as nonınembers, should recognize and respect the diversity within each commumity and recoguize the care that must be exercised in purporting to speak on behalf of a community. ${ }^{178}$

A new perspective on pluralism would encourage interaction between the mamstream and people of color in the following ways. First, immigrants should be encouraged, but not required, to move back and forth between their ethnic commurnties and the mainstream community. This inight mean becoming completely bicultural-that is, able to operate in both spheres smoothly - but it inight not. Knowledge of enough English and Euro-American culture to get by in the mainstream world would be adequate. Ethnic media and bicultural community members can keep people sufficiently informed to participate indirectly in the mainstream comınunity. ${ }^{179}$

Second, and perhaps most important, the mainstream should be encouraged to learn to be bicultural (or multicultural) as well. In a mul-

Hope: The Essential Writings and SPeeches of Martin Luther King, JR. 219 (James M. Washington ed., 1986).

178. For example, the poor state of education for African Americans-in terms of grades and dropout and suspension rates-has led some African American leaders in San Francisco, Detroit, New York, Milwaukee, and Baltimore to call for the creation of all-black schools with an Afrocentric curriculum. However, segments of the African American community, including the NAACP, resist such proposals as anti-integrationist. See David L. Kirp, School Idea Splits Black Community, S.F. EXAMINER, May 2, 1992, at A15.

Elitism among people of color, based on educational or economic privilege, can threaten the solidarity necessary to make a thriving multiculturalism possible. For example, it has never been clear whether integration is the solution desired by the majority of the black community in all circumstances. See, e.g., Brief for CORE as amicus curiae, Swann v. Charlotte-Mecklenburg Bd. of Educ., 402 U.S. 1 (1971) (arguing against a school integration plan). Young urban African Americans' thorough rejection of both "black mainstream culture" as well as "white mainstream culture" further exposes the rifts. See Young Blacks Reject Black, White Mainstream Culture, supra note 158 , at $\mathrm{A} 2$.

179. Of course, filtering media through cultural representatives can be dangerous if it leads to those outside the community identifying the entire community by the standard of the cultural representative, or if the cultural representative's own biases in interpretation are not made clear. However, the problem can be minimized if we are vigilant to the danger. 
ticultural society, the mainstream should be responsible for developing an understanding and knowledge of other cultures. Today, shrewd retailers and business managers already ain to do so. This is not unlike the situation in Europe where students learn inore than one language, something that Euro-immigrationists seem to ignore. Indeed, failing to learn more than one language or more about other cultures could be regarded as imprudent. This perspective recognizes that culture, ethnicity, and identity are not static. One can be one hundred percent Chinese American and also one hundred percent loyal to the United States and its political and economic institutions.

\section{Sharing Core Values}

Ours is a late-twentieth-century world profoundly fissured by nationality, ethnicity, race, class, and gender. And the only way to transcend those divisions-to forge, for once, a civic culture that respects both differences and commonalities-is through education that seeks to comprehend the diversity of human culture. Beyond the hype and the high-flown rhetoric is a pretty homely truth: There is no tolerance without respect-and no respect without knowledge. Any human being sufficiently curious and motivated can fully possess another culture, no matter how "alien" it may appear to be.

-Henry Louis Gates ${ }^{180}$

Even a multicultural society must share a core of values, or a culture, in order to provide a means to live together as a society. Without a commitunent to a coininon core, balkanization into assorted factions is likely. Without a core, eliminating interethnic group violence and tension will be more difficult. This core, however, need not be more than a cominon nucleus. It should respect the need for separatist sentiment, so long as that sentiment does not violate the core values. It should not be an all-encoinpassing concept that defines each person's or each coininunity's total identity. The innage, rather, is one of many cominunities, some more separate than others, some overlapping, but all interlinking at the core.

The common core of values encoinpasses the essence of good citizenship. It includes respect for the laws, ${ }^{181}$ for the denocratic political and economic system, ${ }^{182}$ and for equal opportunity. But this common

180. GATES, supra note 66 , at $\mathrm{xv}$.

181. My intent is that the core leave room for civil disobedience. If people engage in civil disobedience to challenge a law that violates the human values I have listed, the behavior would be consistent with my vision of an American who has accepted the common core values.

182. I realize that including respect for the country's democratic political and economic system as an element of the core is a controversial idea. Many people of color have, with good reason, given up on these institutions as being unjust and racist. I include the qualifier "democratic" in the admittedly idealistic hope that it is through the democratic process that change will occur. 
nucleus is part of a modern vision of being an American. The requirement of inclusion and respect for diversity is reciprocal and applies not only to those in control of the power structure, but also to those at the margin and how they should regard one another. Thus, as part of this core, I would urge upon others a particular set of values-which some would regard as American, but I regard as human values-in order to inove towards a peaceful multiracial society. Basically, these values are to repudiate racism, sexisin, heterosexisin, and class distinctions in our daily activities; to be open, caring, and fair; and to be accepting of diversity and respectful of others. ${ }^{183}$

At first it might seem hypocritical on the one hand to criticize assimilationists for urging immigrants to becoine a certain type of American, but on the other hand to coine up with my own set of normative standards. However, this is not simply a matter of "political correctness." My standards have to do with respect for the lives, identities, and cultures of others. They are standards which promote understanding, unity, and canaraderie, rather than divisiveness, hatred, and violence. Assimilationists only proinote a Euro-American lifestyle and culture and are intolerant of others; my core would seek to promote racial and class harmony, the cornerstone of a multicultural society. I would urge iny nucleus set of values on all Americans, not just inmigrants.

These core values must be followed at the highest levels of governinent and society, by political leaders, government officials, business executives, educators, community representatives, and public figures. Their exainple through words and day-to-day activity is critical. Not only can they set the tone for the repudiation of racism, sexism, heterosexism, and class distinctions, but their actions will demonstrate sincerity about welcoming everyone into the mainstream. The values of respect for the law, support of the democratic and economic systen, fairness, and respect for differences are dependent on the power structure's acceptance of a new vision of pluralism. Without the power structure's imprimatur and resolve, the likelihood of broad-based endorseinent of a common core on the part of those at the inargin inay be inpossible to realize.

\section{CLOSING}

In this article I have urged us to consider anew our vision of pluralism, of what it ineans to be an American, and of what it would take to live in a more peaceful multiracial society. We must begin by recognizing the dangers and the narrowinindedness of race and cultural assimilationists who demand an exclusive Euro-centric vision of

183. In addition, I urge immigrant friends and relatives to learn English, respect the environment, and attend school or find a job. 
America. We should not fear the social impact of new members of our society. While immigrants do gradually influence our culture, market forces cause them to acculturate im rather conventional terms. Furthermore, their influence is positive; they represent a class of people who contribute greatly to society and from whom we can learn. Some espouse separatist sentiment and we should be open to those views in a new vision of pluralism. Developing a new commitment to the elimination of racism at all levels must be a chief priority. We must broaden our vision of what an American is as we strive for a common core of values.

A new understanding of and respect for separatism represents an important starting point for the resolution of interethnic group conflict, as does recognizing that much of the conflict is between the "haves" and the "have nots." This forces us to realize that many communities need creative and meaningful economic assistance and job training prograins. A new consciousness of the insidiousness of racism will also help address many of the problems.

As much as many of us revel in and thrive on multiculturalism and the drive that diversity provides, we cannot deny the tension that multiculturalism brings. Ignoring or glossing over conflict and tension would be a mistake. We must constantly reevaluate and reassess our efforts. ${ }^{184}$ We cannot be overly romantic in our pursuit of a peaceful and productive diversity. Yet, in order to advance, we must not be dernoralized or paralyzed by the tension either. Those working to resolve tension and conflict between and within groups of color, and between communities of color and the power structure and the white working class should be supported. In order to deal with the tension, we must understand its sources. We must remain alert, ever mindful that things can be made better, that we should do the right thing. Ignoring the pressure breeds complacency about inequities and tolerance of racism. Understanding and addressing the tension and pressure allows us to move forward as a society.

Thus, for exainple, the racism within communities of color directed at other communities cannot be ignored, and when it manifests itself in ugly ways, such as rudeness, slurs, discrimination, and violence, it becomes particularly troubling. While the level of racism should not be exaggerated, there is room for improving racial understanding in communities of color as well as across all communities and classes. Every community must take the responsibility for educating its members on the evils of racial hatred. If the primary disagreement is over economic

184. For example, Esther Taira, a Los Angeles school teacher who spearheaded a high school multicultural curriculum in 1986, said that she would design her course differently today. "We do have ethnic-specific courses, but they do not create the bridges we need .... [We cannot ignore] the problems in the streets." Sharon Bernstein, Multiculturalism: Building Bridges or Burning Them?, L.A. TIMEs, Nov. 30, 1992, at A1, A16 (quoting Esther Taira). 
exploitation or political differences, let that be the debate without distorting the discussion with racial enmity.

The problems that communities share can provide a basis for addressing their own racism. Communities of color liave all experienced various forms of subordmation in the United States. The poor among tlien face similar housing and eniployment problenis. Their middle classes face analogous economic difficulty. Their professionals face the same glass ceiling in pronotions. Certainly the Native American and African American communities share a uniquely lorrible history of oppression in the United States because of the involuntary nature of their place in a society donmiated by European Americans. Rather than ranking or conparing degrees of subordination, these groups might find that the sinilarities are sufficient cause for understandinig. Then, by working together on common problenis, interracial understanding is pronioted, and judging others by their cliaracter, rather than by stereotypes based on skin color, is facilitated.

The responsibility for working for solutions lies witlı all sides if racisn and violence are to be eliminated. Dialogue is the first step. Despite the obstacles and problenis, dialogue aniong comniunities of color is possible. Amazingly, only three weeks after the uprising in Los Angeles, Korean American grocers agreed to hire African Anierican gang nienibers. ${ }^{185}$ It took cooperation on both sides to reacl this accord, and niore progress is being niade in spite of the difficulties. The conıniunities have also joined together in peace marclies. In San Diego, a coalition of African Americans and Latinos provide a nodel for engenderimg mutual respect and cooperation. Working witlı churches, comnunity groups, and local government, they conibat conimon problenis sucl as drug use, the lack of low-incone lousing and job training, and violence. ${ }^{186}$

In contrast, Buchanan's proposals, and those of Euroimmigrationists which call for severe inınigration restrictions, do little to address the issues of interethnic conflict and separatisn. Their proposals skirt the liarder issues presented by a social and econonic systen which lias failed groups of color and poor whites. They coninit a foolish error by running froin the tension looping that it will go away if it is iguored for long enougli. Buclianan, Sinipson, and FAIR represent nıany Americans who are unwilling to shoulder the liard work and strain of developing a inulticultural society, wlio cling to an exclusively Euro-conformist definition of an Anierican, or who are just plain racist. Instead, we need to

185. See Gangs, Shopowners Reach L.A. Detente, S.F. EXAMINER, May 26, 1992, at A4 ("The Korean merchants representing the Korean American Grocers Association agreed to consider gang members for jobs. Initially, four gang members, two each from the Bloods and the Crips, would be hired in managerial or other professional positions in Korean-owned businesses.")

186. Listening to America with Bill Moyers (Public Affairs television broadcast, July 2, 1992). 
fashion an approach with hope. Just as we know that culture is constantly changing, the meaning of being an American is also changing to embrace diverse groups. Just as mainstream intolerance for religious discrimination eventually prevailed, the idea of permitting people of color to become Americans on their own terms can also permeate American culture, but only if the racism at the core of exclusionist proposals is exposed and rejected.

Most of us recognize that ethnic conflict, divided neighborhoods, economic competitiveness, and notions of separatism emanating from those subordinated by the power structure are not situations limited to far off lands like Bosma-Herzegovina, the former Soviet Union, and Somahia. But Buchanan's response to those challenges is not the response of a country willing to respond thoughtfully and constructively to racial and ethmic tensions. The right response involves the willingness of all of us, especially the educated, those with influence, and those who have tapped into the economic and political power structures, to acknowledge our responsibility and to fulfill it. Those in control and with options have the power to initiate change. They can set the example for others.

Our nation's slow progress on multiracial and multiethnic issues is bound to spark further separatism. Yet if we remember that separatism is not all evil-especially its emphasis on self-help, identity, and a sense of community-events such as the South Central Los Angeles riots should reinforce our commitment to continue the struggle for a viable multicultural society. South Central was an ugly inanifestation of a society that has failed in many respects-not simply in terms of interethnic group relations. But it reminds us that we cannot continue to ignore the problem. It jolts us into considering new ways of looking at our responsibilities as members of the society.

I know that these notions I advocate can work. I have experienced much of this vision. In my hometown of Superior, I witnessed a community of different classes, backgrounds, and ethnicities thrive. The fact that it is a small town may have helped, but the lessons learned are still valid. There were political and sociological separatists among the Chinese, Navajos, and Mexican Americans. At the same time, however, they were bicultural: they accepted the premise of being part of a larger community. Languages, foods, and values were shared. People of all colors were part of the community: men and women; Mexicans, Navajos, Chinese, Syrians, and whites; bankers, lawyers, copper miners, mine bosses, ranchers, ranch hands, beauticians, grocers, and barbers; Catholics, Mormons, Baptists, Protestants, Jehovah's Witnesses, Episcopalians, Jews, and Buddhists. Of course there were tensions along racial, gender, generational, and class lines, but nothing insurmountable.

Certainly my way of viewing race, culture, self-determination, and 
separatism has significant ramifications not only for Americanization and immigration policies, but also for issues such as affirmative action, integration, the educational curriculum, and educational methods. ${ }^{187}$ How does a modern vision of being an American influence these issues? How does respecting separatist sentiment influence racial preferences and school busing? How does a new pluralism impact what and how students should learn? The issues will become no less complicated when, early in the next century, no racial group comprises a majority of the population. But we can contmue to make sense of these issues, as well as deal with the many tensions we face, if we build an increasing respect for diversity and think in terms of imclusion rather than exclusion. ${ }^{188}$ Our inulticultural society can thrive if we all take responsibility, remaining mindful of who wields power and control, how that power is used, and who has been subordinated and oppressed by that power.

\section{APPENDIX A \\ HistoRicAl NOTES ON THE INFLUENCE OF ASSIMILATIONISTS}

\section{A. Immigration Policy}

Anglo-conformists have long had influence on immigration policies. At least part of the impetus behind the enactment of the Chinese Exclusion Act in 1882 was the behef that Chinese were unassimilable. ${ }^{189}$ In upholding the act, the Supreme Court noted:

The differences of race added greatly to the difficulties of the situation. ... [T] hey remained strangers in the land, residing apart by themselves, and adhering to the custoins and usages of their

187. Somehow we must grapple with the fact, for example, that while whites generally support the concept of equal opportunity, they have tended to avoid African Americans "in those institutions in which equal treatment is most needed." CosE, supra note 75 , at 216 (quoting the conclusion of the National Research Council).

188. For example, bilingual education programs have long been attacked by English-only reformers as fostering separatism. See Rachel F. Moran, The Politics of Discretion: Federal Intervention in Bilingual Education, 76 CALIF. L. REV. 1249, 1301-02 (1988). In my view, this type of stridency ignores the central issue: how to educate non-native speakers of English in a manner that values and respects their cultures, but also teaches them our nation's common values.

189. See Stuart C. Miller, The UnWelcome IMmigrant: The American IMage of the CHINESE, 1785-1882, at 191-93 (1969); SAXTON, supra note 67, at 102-03. In the eyes of many Americans, the diet of the Chinese was different, their language was incomprehensible, their features were unusual, and they had filthy habits. These and other undesirable qualities made them a menace. See Hutchinson, supra note 28, at 59 (1981). Later, many Amerieans viewed the Japanese as an economic and racial threat. See HigHAM, supra note 28, at 165-66; SAXTON, supra note 67, at 247-49. There also was fear of "mongrelization" of California due to Filipino social interaction with white women. See Howard A. DEWITT, ANTI-FILIPINo MovemENTS IN CALIfornia: A History, Bibliography aNd Study GuIDE 67 (1976). The government responded with exclusion laws, alien land acts, antimiscegenation statutes, and Japanese internment. The mainstream's nativism resulted in notorious examples of discrimination, vandalism, and violence levied against Asian immigrants. 
own country. It seemed impossible for them to assimilate with our people or to make any change in their habits or modes of living. As they grew in numbers each year the people of the [West] coast saw, or believed they saw, in the facility of inmigration, and in the crowded millions of China, ... great danger that at no distant day that portion of our country would be overrun by them unless prompt action was taken to restrict their immigration. ${ }^{190}$

Much of the concern about immigration at this time was due not only to the numbers of new immigrants, but also to their particular national origin and ethnicity. Before the 1880 s, the majority of immigrants to the United States came from Northern and Western Europe; during the last two decades of the nineteenth century, approximately seventy percent of European immigrants arrived from countries in Southern and Eastern Europe, and the numbers from Asia and Latin America increased. Thus, "by 1900 there were growing fears in the country about botli the quantity and quality of new immigrants, especially those from Southern and Eastern Europe-Itahans, Jews, and Slavs-who seemed unwilling or unable to assimilate to Anglo-American culture."191

Concerns over assimilation led to an early Englisli-only moveinent. In 1894, the California Constitution was amended to restrict the vote to those who could read and write Englisl and to require official government proceedings to be conducted and published in English. ${ }^{192}$ In 1906, Congress enacted a new English language requirement for U.S. citizenship. ${ }^{193}$

An immigration explosion in the first decade of the twentieth century ${ }^{194}$ led to lieightened concern over the impact of immigrants. Congress commissioned a study whicl asserted that the new immigrants were not learning English and were not willing to assimilate as quickly as the Germans and Scandinavians had done. Indeed, the new immigrants were

190. Chae Chan Ping v. United States (The Chinese Exclusion Case), 130 U.S. 581, 595 (1889). The Court went on to find that "[i]f . . . the government of the United States, through its legislative department, considers the presence of foreigners of a different race in this country, who will not assimilate with us, to be dangerous to its peace and security, their exclusion is not to be stayed." Id. at 606. It is interesting that the Chinese were perceived as "adhering to [their old] customs and usages," considering that most immigrants in fact acculturate. The question, rather, is whether they are able to enter mainstream institutions and structurally assimilate. In the case of the Chinese in the $1880 \mathrm{~s}$, it is doubtful that white society allowed them much opportunity to assimilate, given the wide range of discriminatory laws directed at them.

191. Carlos J. Ovando, Politics and Pedagogy: The Case of Bilingual Education, 60 HARV. EDuc. REV. 341, 345 (1990).

192. See CAL. CoNST. art. III, $\$ 1$ (repealed 1972).

193. Law of June 29, 1906, ch. 3592, §8, 34 Stat. 596, 599 (repealed 1940).

194. From 1901-10, 8,795,386 immigrants entered the U.S. This figure is greater than in any other decade, before or since. See 1989 INS STAT. Y.B. 3 tbl. 2. 
viewed darkly by many American politicians and educators, and tlought to suffer from high levels of feeble-mindedness, disloyalty, Popery, and other shortcomings. [A popular book] warned that 'the population of the United States will, on account of the great influx of blood from South-eastern Europe, rapidly become darker in pigmentation, smaller in stature, more mercurial, more attached to music and art, more given to crimes of larceny, kidnapping, assault, murder, rape, and sex-immorality ... [and] the ratio of insanity im the population will rapidly increase.'195

The English language remained a focal point of much of the concern over assimilation. "Americanization" campaigns of the first two decades of the century linked "the ability to speak English ... ideologically and politically to American loyalty and patriotism." 196 In 1919, fifteen states legislated Enghish as the basic language of instruction in schools as a result of these cainpaigus. ${ }^{197}$ Theodore Roosevelt expressed the tenor of the times when he asserted in 1919, "We have room for but one language in this country and that is the Enghish language, for we intend to see that the crucible turns our people out as Americans, of American nationality, and not as dwellers in a polyglot boarding house." 198

In their zeal to promote Enghish, assimilationists attempted to ban other languages in elementary schools. In 1923, the Supreme Court nullified such restrictive state laws in Meyer $v$. Nebraska ${ }^{199}$ by striking down a Nebraska law prohibiting the teaching in school of any language other than English (here directed at German) before the eighth grade. But at the same time, the Court upheld the right of the state to require instruction in English. Justice McReynold's opinion makes clear the extent to which language restriction was tied to Americanization sentiment at the time:

It is said the purpose of the legislation was to promote civic development by inhibiting training and education of the immature in foreigu tongues and ideals before they could learn Enghish and acquire American ideals; and 'that the English language should be and become the mother tongue of all children reared in this State.' It is also affirmed that the foreign born population is very large, that certam commumities commonly use foreign words, fol-

195. Harvey A. Daniels, The Roots of Language Protectionism, in Not ONLY ENGLISH: AfFirming America's Multilingual Heritage 3, 8 (Harvey A. Daniels ed., 1990) (citation omitted). While Mexicans were also considered undesirable as citizens, the congressional study concluded that they were needed as cheap labor for the expansion of industry and the development of natural resources. López, supra note 52, at 657 .

196. Ovando, supra note 191 , at 345 .

197. Id.

198. James Crawford, Bilingual Education: History, Polmiti, Theory and Practice 23 (2d ed. 1991) (quoting Theodore Roosevelt).

199. 262 U.S. 390 (1923). 
low foreign leaders, move in a foreign atınosphere, and that the children are thereby hindered froin becoming citizens of the most useful type and the public safety is imperiled.

The desire of the legislature to foster a homogeneous people with American ideals prepared readily to understand current discussions of civic matters is easy to appreciate. Unfortunate experiences during the late war and aversion toward every characteristic of truculent adversaries were certainly enough to quicken that aspiration. ${ }^{200}$

Anxiety over the contimued entry of large numbers of allegedly unassimilable mimigrants led to restrictive inmigration policies in the 1920 s. $^{201}$ In 1924, Congress enacted the National Origins Quota Act, which provided for an annual limit of 150,000 immigrants from Europe, baimed immigration from Japan, ${ }^{202}$ and established quotas based on the proportional representation of each nationality in the 1890 population of the Umited States. Simce the vast majority of the 1890 population was of Northern European derivation, ${ }^{203}$ the Act effectively reduced linguistic and cultural differences by "limit[ing] immigration from countries which did not share our language, traditions and political system."204

Congress did not replace the national origins quota system until $1965 .^{205}$ Although the resulting system was more egalitarian, it was enacted in large part to advance white, English-speaking immigration. ${ }^{206}$

200. Id. at 401-02. Counsel for the plaintiff in error in Meyer strongly asserted that "in our desire for the Americanization of our foreign born population we should not overlook the fact that the spirit of America is liberty and toleration-the disposition to allow each person to live his own life in his own way, unhampered by unreasonable and arbitrary restrictions." Id. at 392 . The opinion of the Court did not specifically endorse this view.

201. Congress enacted the first national origins quota law in 1921 and made the provisions permanent in 1924. See HiGHAM, supra note 28, at 316-24; HUTCHinson, supra note 28, at 180-94.

202. By 1924, Congress had already banned other Asian immigration. See HiNG, supra note 11, at 23-33.

203. See Hutchinson, supra note 28 , at 483-84.

204. Bill Piatt, Only English?: Law and Language Policy in the United States 18 (1990).

205. The 1965 amendments exemplify the impact of cultural pluralists on immigration policies. After years of unsuccessful efforts by Presidents Truman and Eisenhower to eliminate the quota system, President Kennedy submitted a comprehensive program that provided the impetus for ultimate reform. His proposals reflected his longstanding interest in immigration reform. Kennedy called for the repeal of racial exclusion from the Asia-Pacific triangle, and he assailed the nativism that led to the Chinese exclusion laws as well as the national-origins system of the 1924 law.

President Kennedy's hopes for abolishing the quota system were realized after his assassination when the 1965 amendments were enacted. But his vision of visas on a first-come, first-served basis gave way to a narrower and more historically parochial framework. The new law allowed 20,000 immigrant visas for every country not in the Western Hemisphere. This was not exactly what President Kennedy had envisioned, but at least the national-origins selection system was eliminated, which was something that neither Truman nor Eisenhower could accomplish. See Hing, supra note 11 , at $36-41$.

206. Id. at 7. 
Its family reunification emphasis, for example, under which more than eighty percent of the visas went to family members, was premised on the assumption that relatives of the predominantly white European mainstream would dominate subsequent immigration. Furthermore, the new laws set quotas based on hemispheric origin: 170,000 people could enter from the Eastern Hemisphere and 120,000 from the Western Hemisphere. ${ }^{207}$ Separate hemispheric quotas remained in effect until 1978, reflecting "[1]ingermg nativism . . . directed against immigrants froin Mexico and Central and South America."208

Legislation enacted in the last decade deinonstrates the continuing influence that Anglo-conformists hold. Under the Immigration Reform and Control Act of 1986, legalization (amnesty) applicants must satisfy requirements relating to Enghish literacy and knowledge of United States history and government. While such requirements are coinmon for immigrants seeking to become naturalized citizens, never before had such requirements been imposed on persons simply seeking immigrant status. ${ }^{209}$ Legislation passed in 1990 gave special preference to Irish inmigrants, in part because of their English-speaking ability. ${ }^{210}$

As part of the 1986 immigration legislation, Congress also added a provision to help would-be immigrants from thirty-six countries that had been "adversely affected" by the 1965 changes. ${ }^{211}$ To inake the list of those adversely affected, a country must have been issued fewer visas after 1965 than before 1965 . Thus, given the strict pre-1965 racial quotas for non-European countries, the list of adversely-affected countries did not include any African or Asian countries except for Japan. ${ }^{212}$ The 1986 law provided an extra 5000 such visas a year to these "adversely affected" countries for 1987 and 1988; Congress later increased the number of additional visas to 15,000 per year for 1989 and $1990 .{ }^{213}$

207. Id. at $40 \&$ n.203.

208. P1ATT, supra note 204 , at 19-20.

209. Bill ONg Hing, HaNdling Immigration Cases $\S \S 4.2-.71$ (1985). Those requirements have traditionally only been imposed on immigrants applying for citizenship through naturalization. Id. $\S 11.21$.

210. Legislative proposals which led up to the 1990 legislation were based on a point system which gave points to prospective immigrants literate in English, but gave no points for literacy in other languages. Cf. Kennedy, Donnelly Introduce Legal Immigration Reform Bills, 64 INTERPRETER RELEASES 940, 941 (1987); U.S. Should Revise Immigration Laws Based on Job Market Needs, Cornell Professor Says, Daily Lab. Rep. (BNA) No. 248, at A1 (Dec. 29, 1987). While the resulting legislation did not contain a blatant point system, under a "transition diversity program" in effect until 1994, 40,000 visas are available each year and $40 \%$ of those visas are reserved for Irish nationais. See HiNG, supra note 209, § 4.22C (Supp. 1993).

211. HiNG, supra note 209, $\S 4.22 B$ (Supp. 1993).

212. Id.

213. Immigration Amendments of 1988, Pub. L. No. 100-658, § 2, 102 Stat. 3908 (1990). 


\section{B. Americanization Programs}

One short-lived government-sponsored Americanization programfrom 1915 to 1929 -was aimed directly at Mexican immigrants. In 1900 , about 100,000 persons of Mexican descent or birtll resided in the United States. By 1930, the figure was 1.5 million. ${ }^{214}$ While restrictionists and employers who claimed a need for cleap labor battled over future Mexican immigration, a third group of "Americanists" sought to assimilate Mexican immigrants. By 1913, California Governor Hiram Johnson was able to establish a Commission on Immigration and Housing, which directed efforts to teach English to immigrants and involve them in Americanization programs. ${ }^{215}$ The Commission focused its attention on Mexican immigrant women, in the belief that they were primarily responsible for the transmission of values in the home. School districts employed special classes and "home teachers," hoping that Mexican women would pass on their newfound values to children and their lusbands.

The Americanization program cast a broad net over many aspects of the immigrants' lives, with mucl of the program based on insidious stereotypical beliefs about Mexicans. The Commmission considered developmg Enghish-speaking ability the fundamental goal, not simply for facilitatimg a common language, but because it would help imbue immigrants with the values of American society by helping them see "the relation between a unified working force, speaking a common language, and mdustrial prosperity."216 Family planming was a key ingredient because progressives and nativists alike feared that uncontrolled Mexican immigrant population growtl would contribute to Anglo "race suicide."217 The development of a work ethic outside the home was considered important so that Mexican women could fill the labor need for domestic servants, seamstresses, laundresses, and service workers in the Southwest; it would also contribute to " 'curing' the habits of the stereotypical 'lazy Mexican." "218 Getting the Mexican woman out of the

214. George J. Sanchez, "Go After the Women": Americanization and the Mexican Immigrant Woman, 1915-1929, in UNEQUal Sisters: A MUlTicultural READER IN U.S. WOMEN'S History 250, 251 (Ellen C. DuBois and Vickie L. Ruiz eds., 1990).

215. Id. at 254.

Though governmental bodies and private organizations in other states also sought to Americanize Mexicans, California's program was the most complete attempt to bring together government, business, and private citizens to deal with the "problem of the immigrant" in a scientific and rational fashion. The Commission successfully recruited university academies, religious social workers, government bureaucrats, and middle-class volunteers.

Id.

216. Id. at 256 (citing the California Commission on Immigration \& Housing).

217. Id. at 258 .

218. Id. at 259 . 
home was also considered necessary to alter her values because at home her intellectual ability would not be stimulated by her husband.

Americanization programs taught food and diet management because a healthy diet was viewed as fundamental for creating productive members of society. ${ }^{219}$ Mexicans were to give up their penchant for fried foods; tortillas would be replaced with bread and lettuce served instead of beans. ${ }^{220}$ The typical noon lunch for the Mexican child, thought to consist of a folded tortilla with no filling, was supposedly the first step in a life of crime, since the child would be tempted to steal from the other children. ${ }^{221}$ Furthermore, health and cleanliness were emphasized since program directors felt that Mexicans could not easily learn sanitation and hygiene because they found it less exerting "to remain dirty than to clean up."222

In the end, the Americamization program aimed at Mexican women had little impact on cultural practices. Certainly, an increase in female employment in factories, laundries, hotels, and bakeries may have been facilitated by these efforts, but in the home, little cultural change among the Mexican population was evident. ${ }^{223}$ While the Mexican immigrants' material possessions changed, their values, cultural practices, and loyalty to Mexico remained largely unaffected. ${ }^{224}$ By the time of the Great Depression in the 1930s, the Americanization program stopped, restrictiomist sentiment carried the day, and approximately 500,000 Mexicans returned to Mexico "under strong pressure from the government."225

Anglo-conformity assimilation programs were not limited to immigrants. From the 1870s to the 1930s, the Americanization movement implemented "an all-out assault on every facet of [Native American] culture-property, language, appearance, religion, economy, political form and even thought." ${ }^{226}$ The removal of most of the eastern and southern Native American tribes to the trans-Mississippi region by the 1840 s was designed not only to secure state jurisdiction over Native American lands, but also to inculcate the people with the essentials of the white man's civilization. ${ }^{227}$ Reservations were not only designed to remove Native Americans from the path of advancing whites, but also as a tool of control. ${ }^{228}$

The purported purpose of assimilation was to encourage Native

219. Id. at 257.

220. Id.

221. Id.

222. Id. at 255 .

223. Id. at 259-60.

224. Id. at 260.

225. Id. at 261.

226. Ragsdale, supra note 80 , at 400 .

227. Id. at 401.

228. Id. at 402 . 
Americans to inodify their traditional life by emulating superior white civilization and striving for agrarian self-sufficiency. But many of the methods used constituted inore of "a systemic policy of cultural annihilation." 229

Assimilation sought to replace the central beliefs of a tribal society with Western European societal and religious values. The white reformers sought to instill the concept of "competitive individualism" in Native Americans, supplanting the inore cooperative spirit of tribal life. ${ }^{230}$ The reformers stressed respect for private property, especially land. Merrill Gates, the leader of the reform group the Friends of Indians, said in 1896, "We have, to begin with, the absolute need of awakening in the savage Indian broader desires and ampler wants. To bring hin out of savagery into citizenship we inust make the Indian more intelligently selfish before we can inake him unselfislily intelligent. We need to awaken in him wants."231 The assimilationist movennent, which was directed by Christian reformers, felt that tribal deities had to be replaced with the Christian God. ${ }^{232}$

Tribal culture was suppressed by direct regulation of certain aspects of Native American belhavior. Reservation agents and Bureau of Indian Affairs (BIA) administrators restricted liair length, limited funeral practices, meat slaughtering techniques, dancing, plural inarriages, and religious observances. ${ }^{233}$

Like Americanization programs aimed at Mexican immigrants, Native American Americanization programs also targeted family values. Where Mexican women were targeted, however, a different tactic was used with Native Americans. Federal authorities targeted young Native Americans for a thorough restructuring of their values in the hopes that the (inferior) Native American cultures and heritages would be destroyed at their roots. By 1870, the federal goverument was funding off-reservation schools under the auspices of religious groups. ${ }^{234}$ Native American parents were pressured and coerced into sending their children away to these schools under threats of withholding food, clothing, or money. Reluctant children were hunted down and physically transported to schools against their will. ${ }^{235}$ Once there, they were isolated for up to eight years and not permitted to see their families. They could not wear native clothing, speak their native tongues, practice native customs, or retain their own names. ${ }^{236}$ The philosophy was, to quote Richard Pratt,

229. Id.

230. Id. at 403.

231. Id. at 404 (quoting Merrill Gates).

232. Id. at 404-05.

233. Id. at 407-08.

234. Id. at 410 .

235. Id.

236. Id. 
the founder and head of the Carlisle School for Indians in Pennsylvania, to "kill the Indian in him, and save the man."237

In the end, the isolation and transformation killed Native American cultural values and left the young Native Americans disoriented and ostracized. Sent out into the white world, they were spurned because of their racial features and class status, notwitlistanding their "Americanization." Those wlio returned to the reservation found themselves in a foreign and unfamiliar cultural landscape. ${ }^{238}$

Eventually, private access to Native American lands declined and the impetus for assimilation correspondingly diminislied. ${ }^{239}$ The movement also faltered in part because of the emergence of a racist perspective that Native Americans could not reacli the accoinphishinent levels of the white race. ${ }^{240}$ Other factors which led to the termination of the assimilation programs included the fading of religious and scientific transcendent ethics, the increasing secularization of society, ${ }^{241}$ and studies by anthropologists and etlinologists which contributed to the public's awareness of the deptli, coinplexity, and uniqueness of the Native American cultures. ${ }^{242}$ In the 1920s, white artists and intellectuals from Taos and Santa Fe rallied behind the Pueblo tribes to oppose legislation that would have aided white squatters in their land claims against the Pueblos; their success awakened much of the country to the values of Native American culture and to the threat posed by the ongoing policies of assimilation. ${ }^{243}$

\section{APPENDIX B \\ EXAMPLES OF IMMIGRANT AsSimilation STUdies}

Sociological studies on immigrant assimilation slow that culture is not a zero-sum quantity where a gain is necessarily acconipanied by loss. An individual's culture is not a fixed quantity; it can grow and develop without necessarily displacing another element. For exanıple, post-1965 Asian inunigrants have not followed a Euro-conformity model of assiniilation. Even a cursory examination of Asian conımunities shows the maintenance of a vital Asian American community: pockets of residential and econounic enclaves of Asian Americans thrive; Asian languages are spoken frequently; Asian language nedia is on the increase; Asian Americans are denianding a variety of educational and social services fron the government. But does this necessarily mean that a culturalpluralisnı approaclı has einerged?

237. Id. (quoting Richard Pratt).

238. Id.

239. Id. at 422 .

240. Id. at $422-23$.

241. Id.

242. Id.

243. Id. at 423. 
In the Korean American community, for instance, immigrants have followed a mode of cultural adaptation that is not accompanied by their detachment from Korean culture. ${ }^{244}$ A 1979 survey of 615 Korean immigrants in the Los Angeles area found a relatively low degree of adaptation to new American habits, customs, and tastes, with a strong attachment to native culture and society. ${ }^{245}$ This high degree of ethnic attachment was not related to the length of residence in the United States. ${ }^{246}$ On the other hand, length of residence and level of Anierican education were both positively related to the degree of attachment to new American custonis. ${ }^{247}$ For example, the proportion of respondents who subscribed to American newspapers increased in relation to length of residence in the Umited States, whereas a great niajority subscribed to Korean newspapers regardless of the length of residence. ${ }^{248}$ Thus, Korean immigrants demonstrated that the two cultures, American and Korean, were not nutually exclusive; they could acculturate while still retaining niany of their traditions.

A study of the pattern of Japanese American adaptation yielded similar observations. Japanese Americans maintained their heritage but adopted niany aspects of American life. The study found significant compatability, but not identity, between Japanese American and white manistream values and behaviors. ${ }^{249}$ The process of Aniericanization of Southeast Asian refugees reveals a degree of sociological separatism. The initial government resettlement plan was intended to disperse Vietnaniese refugees widely and avoid enclaving. ${ }^{250}$ In that respect, it represented a rough outlime for Anglo-conformity. However, the refugees ignored the resettlenient plans imposed on then1, opting instead to relocate to areas closer to former friends, family, and those with sinilar backgrounds. ${ }^{251}$

That Southeast Asians have elected such an assinilation process

244. See Won Moo Hurh \& Kwang Chung Kim, Adhesive Sociocultural Adaptation of Korean Immigrants in the U.S.: An Alternative Strategy of Minority Adaptation. 18 INT'L MIGRATION REV. 188, 205 (1984). Hurh and Kim describe the mode of adaptation as "additive" or "adhesive" adaptation. Similarly, Erich Rosenthal observed that the high level of acculturation among Jewish immigrants in the Chicago area was not accompanied by a decline in Jewish ethnic consciousness and attachment-a case of "acculturation without assimilation." See Erich Rosenthal, Acculturation Without Assimilation? The Jewish Community of Chicago, Illinois, 66 AM. J. Soc. 275, 282-88 (1960).

245. Hurh \& Kim, supra note 244, at 192-96. The data on acculturation had three dimensions: English proficiency, exposure to American-printed mass media, and Anglicization of Korean first names. Social assimilation was examined in terms of the nationality and ethnic background of friends and participation iu American voluntary associations. Id. at 193-95.

246. Id. at 197.

247. Id. at $196-200$.

248. Id. at 198 .

249. See Minority Responses: Comparative Views of Reactions to Subordination 131-33 (Minako Kurokawa ed., 1970).

250. See HiNG, supra note 11, at 129.

251. See Paul J. Strand \& Woodrow Jones, Jr., Indochinese Refugees in America: Problems of Adaptation AND Assimilation 131 (1985). 
should come as no surprise. They have had to deal with the shock of relocation to the United States and with the difficulty of adjusting to a new lifestyle. ${ }^{252}$ Uprooted by war, they were forced to seek refuge in the United States, rather than make a conscious, planned decision to emigrate. It is natural for thein to cling to community, tradition, and culture. Adaptation through increasing economic power and contact with the mainstream society has not been an avenue followed by most Southeast Asians, due in part to racial prejudice and a lack of English facility and other job skills. ${ }^{253}$

Studies of other immigrant groups yield similar findings. In a study of Cuban immigrants in Washington, D.C., fifteen years after the Cuban Revolution in 1959-60, one researcher found that "[i]n spite of similarities in adjustment, each group creates a urique cultural blend. Sorne traditional values are retained, and other, less useful customs are discarded."254 A study of 850 Pakistari imnigrants who settled in Michigan revealed that the longer the immigrant had resided in the United States, the more noticeable the change in daily habits and attitudes, and the greater the influence of friends and colleagues. ${ }^{255}$ Seldoin did these imnnigrants change their preference for Pakistani food, and some women retained their preference for Pakistain clothes. ${ }^{256}$ While religion is a very miportant social institution in Pakistan, religion beconres less institutional to many Pakistani immigrants, although soine becaine more religious and conservative as a result of "strong doubts and suspicions about American moral standards."257

252. See id. at 138 .

253. See id. at 131-38.

254. Margaret S. Boone, Capital Cubans: Refugee Adaptation in Washington D.C. 1 (1989).

255. Iftikhar H. Malik, Pakistanis in Michigan: A Study of Third Culture and ACCULteration (sic) 114-15 (1989).

256. Id. at 117 .

257. Id. at 130 . 


\section{California Law Review}

\begin{tabular}{lll}
\hline \hline Vol. 81 & JULY 1993 & No. 4 \\
\hline
\end{tabular}

Copyright $(\mathcal{C} 1993$ by California Law Review, Inc.

\section{BOARD OF EDITORS}

1992-93

Editor-in-Chief

Thomas L. FREEDMAN

Managing Editor

STEVEN CHERENSKY

Senior Articles Editor

RHONDA R. TROTTER

Articles Editors

Daina C. Chiu

W. STUART HIRSCHFELD

JOEL S. JACOBS

ANDREW E. NAGEL

Book Review Editor

KYIE HOFFMAN

Bradley A. Benbrook Elizabeth A. Di Cola BRIAN J. FOLEY

GARY GOLD

JAY HARKER

Christine L. Hoang

JESSE BERG

Daniel P. Doporto

BenJamin L. Douglas

Cheryl Dyer

DAvid T. EMERSON
Senior Executive Editor

William H.D. FERnholz

Executive Editors

Nicole ANDERSON

GREGORY MITCHELL

JEFFREY P. RAKE

Production Editor

ROBERT M. SHORE

Associate Editors

ANN H. KIM

BRIAN C. LEE

ChRistopher R. LesLie

J. KeITH ORVILLE

EUGENE PAK

\section{Members}

SUSANNAH T. French GWYNETH E. HAMBLEY

SHARON L. IRVING

JEFFREY KUPOR

Office Manager

KAREN E. FASS
Senior Notes \& Comments Editor

Daniel J. Cloherty

Notes \& Comments Editors Steven De Salvo

ROBERT A. Holland

StEPHANIE L. Siegel

Research \& Topics Editor ANN CHIGA

JULIA PARRY

Karl A. Sandoval

Michael B. SchWARZ

CIINT N. SMITH

CRaig Varnen

David S. Welsh

Timothy A. PORTER

Michael Prough

JESÚS G. ROMÁN

Mitchell J. Steinberger

MiChaEL S. UMANSKY 


\section{California Law Review}

\begin{tabular}{lll}
\hline \hline VoL. 81 & JULY 1993 & No. 4 \\
\hline \hline
\end{tabular}

Copyright $\odot 1993$ by California Law Review, Inc.

\section{BOARD OF EDITORS}

1993-94

\section{Senior Articles Editor}

Thomas J. Peckham

NANCY COMBS

Articles Editors

DAN S. SOKOLOV

Philip C. TENCER

GEORGE L. WASHINGTON, JR.

Book Review Editor

JAMES M. AQUILINA

JefF CARIISLE

TRACY FRIEDMAN

ANDREW HACKBERT

I. JAY KUO

FABIO ARCILA JR.

ERIK BABCOCK

ERIC DOBMEIER

ROGER DOUGHTY

JODY FOSTER
Editor-in-Chief

ANUJ R. DESAI

Managing Editor

VIVIAN B. DISTLER

Senior Executive Editor

NICOLE M. RYAN

Executive Editors

STEVE GEARY

TODD NOONAN

CATHy J. OstilleR

Production Editor

JAN E. TOMSKY

Associate Editors

Matt Levett

JENNIFER OCHS

Daniel Pines

RICK E. RAYL

FRANK SOLOMON

\section{Members}

David E. Goldstein

LISA A. LAEHY

SyLVIA LEONG

Craig Norris

Office Manager

KAREN E. FASS
Senior Notes \& Comments Editor

Frank Cialone

Notes \& Comments Editors

JAMES KNOX

Flavio Rose

SARAH C. WILSON

Research \& Topics Editor

BeAtrice B. NguYeN

Molly S. Stump

Christine H. SuH

Marsha TOdD

BRIAN M. TORRES

Ellen J. RubiN

DAVID W. SIMON

RUSSELL SOMMERS

KATHRYN E. SuAREZ

TIMOTHY J. WALSH 
